\title{
Microbial diversity and biogeochemical cycling in soda lakes
}

\author{
Dimitry Y. Sorokin • Tom Berben • \\ Emily Denise Melton · Lex Overmars • \\ Charlotte D. Vavourakis • Gerard Muyzer
}

Received: 30 May 2014 / Accepted: 26 June 2014/Published online: 26 August 2014

(C) The Author(s) 2014. This article is published with open access at Springerlink.com

\begin{abstract}
Soda lakes contain high concentrations of sodium carbonates resulting in a stable elevated $\mathrm{pH}$, which provide a unique habitat to a rich diversity of haloalkaliphilic bacteria and archaea. Both cultivation-dependent and -independent methods have aided the identification of key processes and genes in the microbially mediated carbon, nitrogen, and sulfur biogeochemical cycles in soda lakes. In order to survive in this extreme environment, haloalkaliphiles have developed various bioenergetic and structural adaptations to maintain $\mathrm{pH}$ homeostasis and intracellular osmotic pressure. The cultivation of a handful of strains has led to the isolation of a number of extremozymes, which allow the cell to perform enzymatic reactions at these extreme conditions. These enzymes potentially contribute to biotechnological applications. In addition, microbial species active in the sulfur cycle can be used for sulfur remediation purposes. Future research should combine both innovative culture methods and stateof-the-art 'meta-omic' techniques to gain a comprehensive
\end{abstract}

This article is part of a special issue based on the 10th International Congress on Extremophiles held in Saint Petersburg, Russia, September 7-11, 2014.

Communicated by A. Oren.

D. Y. Sorokin

Winogradsky Institute of Microbiology, RAS, Moscow, Russia

D. Y. Sorokin

Department of Biotechnology, Delft University of Technology, Delft, The Netherlands

T. Berben · E. D. Melton - L. Overmars ·

C. D. Vavourakis · G. Muyzer $(\bowtie)$

Institute for Biodiversity and Ecosystem Dynamics, University of Amsterdam, Amsterdam, The Netherlands

e-mail: g.muijzer@uva.nl understanding of the microbes that flourish in these extreme environments and the processes they mediate. Coupling the biogeochemical $\mathrm{C}, \mathrm{N}$, and $\mathrm{S}$ cycles and identifying where each process takes place on a spatial and temporal scale could unravel the interspecies relationships and thereby reveal more about the ecosystem dynamics of these enigmatic extreme environments.

Keywords Biogeochemical cycling · Haloalkaliphile · Halophile · Meta-omics · Soda lake · Systems biology

\section{Introduction}

Soda lakes are found worldwide, predominantly in arid and semi-arid environments, such as the Rift Valley in East Africa, the rain-shadowed regions of California and Nevada, and the Kulunda Steppe in South Siberia (Russia) (Fig. 1). Soda lakes are formed in depressions where ground water rich in carbon dioxide, but poor in magnesium and calcium, leaches sodium from sodium-rich rocks. The absence of dissolved divalent cations is crucial to avoid carbonate precipitation. During arid climate conditions in closed basins, carbonate salts become more concentrated due to increased evaporation rates, leading to the formation of natural sodium carbonate/bicarbonate-buffered systems with elevated $\mathrm{pH}$ values $(9.5-11)$ and salt concentrations up to saturation (Tindall 1988; Grant et al. 1990). The chemical composition of the prevailing salts leads to perfect conditions for haloalkaliphiles to thrive. Natronophily indicates a preference for sodium carbonates over sodium chloride, the dominant salt in thalassic (hyper)saline environments, and is based on the fundamental difference in the electrolytic and osmotic properties of these two sodium salts (Banciu et al. 2004; Banciu and 
Sorokin 2013). Low and moderately saline soda lakes (total salinity between 35 and $50 \mathrm{~g} / \mathrm{L}$ and 50 and $250 \mathrm{~g} / \mathrm{L}$, respectively) are highly productive and harbor fully functional and diverse haloalkaliphilic microbial communities responsible for the cycling of chemical elements, such as carbon, nitrogen, and sulfur. Under hypersaline conditions (total salinity $>250 \mathrm{~g} / \mathrm{L}$ ) the diversity is restricted to a few extremely salt-tolerant specialists (Ochsenreiter et al. 2002; Mesbah et al. 2007). The carbon and nitrogen cycles are presumably partly inhibited, as follows from the lack of cultured methanotrops at moderate salinity (Sorokin et al. 2000; Trotsenko and Khmelenina 2002) and the cessation of nitrification at high salt concentrations (Sorokin 1998).

Soda lakes are 'treasure troves' for biotechnologists, because they harbor extremophiles with the potential to produce enzymes (extremozymes) that are active both at a high $\mathrm{pH}$ and high salinity. Alkali-stable extracellular proteases, lipases, and cellulases have been used for the production of improved laundry detergents (Horikoshi 2006). Halo-alkali-stable cellulases can also be used to release sugars from recalcitrant lignocellulose in agricultural waste for the production of bioethanol. These enzymes have an additional advantage, because ionic liquids (organic analogues of inorganic salts) are frequently used during pretreatment in the solubilization of (ligno) cellulosic biomass (Zhu 2008; Zavrel et al. 2009; Zhang et al. 2011). Besides the discovery of novel hydrolases, a novel nitrile hydratase was isolated from the soda lake Actinobacterium Nitriliruptor alkaliphilus (van Pelt et al. 2008; Sorokin et al. 2009). Nitrile hydratases are important industrial enzymes that catalyze the hydration of a broad scope of nitrile compounds into commercially more valuable amides (e.g. acrylamide). Apart from these extremozymes, whole cells of haloalkaliphiles can be used for the sustainable removal of toxic sulfur compounds from wastewater (Janssen et al. 2009; de Graaff et al. 2011) and gas streams (van den Bosch et al. 2007; Sorokin et al. 2008f; Janssen et al. 2009), and for the biodegradation of hydrocarbons and other organic (e.g. nitro-aromatics) and inorganic (e.g. arsenic, uranium) pollutants (Sorokin et al. 2012c).

Here we present an overview of the cultured (Fig. 2 and Table 1) and uncultured bacterial and archaeal diversity of
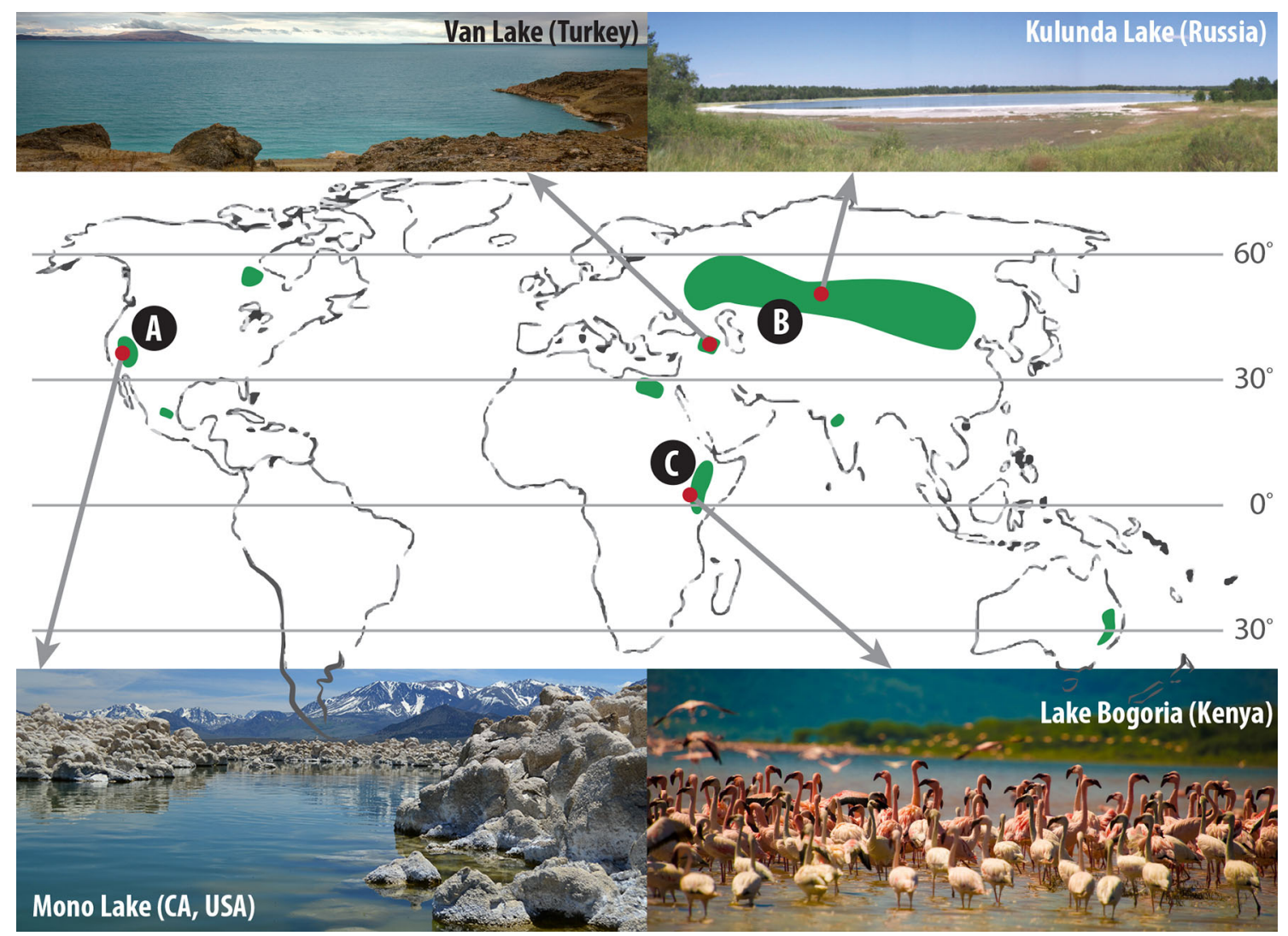

Fig. 1 World map depicting major areas where soda lakes occur (green). A Rain shadowed area of California and Nevada. Mono Lake is depicted (photograph by Sacha Heath). $B$ Eurasian Steppe contains the Kulunda steppe and Kulunda Lake. $C$ Rift Valley contains many soda lakes, such as Lake Bogoria (photograph from Shutterstock).
Shown in the top left is Van Lake in Turkey (photograph from Shutterstock). Also indicated are the Central Mexican plateau, Manitoba (Canada), Wadi al Natrun (Egypt), Decan Plateau (India), and Eastern Australia 
soda lakes and focus on the role of these microorganisms in the biogeochemical carbon, nitrogen, and sulfur cycles. In addition, we discuss the molecular mechanisms that allow these haloalkaliphilic prokaryotes to thrive at the doubleextreme conditions of high $\mathrm{pH}$ and high salinity.

\section{Cultured diversity and their role in biogeochemical cycles}

The carbon cycle

\section{Carbon fixation}

Autotrophic primary producers in soda lakes able to fix inorganic $\mathrm{CO}_{2}$ into organic polymers include oxygenic and anoxygenic haloalkaliphilic phototrophs and some chemolithoautotrophs (Fig. 3a1). The primary production in most soda lakes is high due to a dense population of haloalkaliphilic cyanobacteria (Melack 1981; Kompantseva et al. 2009). They include unicellular and filamentous heterocystous and non-heterocystous groups. The planktonic cyanobacterial forms, which are dominant in tropical soda lakes in Kenya and Ethiopia (Fig. 1), include the genera Arthrospira (Spirulina), Anabaenopsis and Cyanospira (Dubinin et al. 1995; Ballot et al. 2009; Dadheech et al. 2013; Krienitz et al. 2013). Hypersaline soda brines are dominated by the extremely haloalkaliphilic unicellular cyanobacterium 'Euhalothece natronophila' (Mikhodyuk et al. 2008). Haloalkaliphilic cyanobacteria are most dominant at moderate salinity, whilst at higher salt concentrations only extremely salt-tolerant unicellular green algae, such as Dunaliella viridis and Picocystis salinarium, can thrive (Gerasimenko et al. 1999; Krienitz et al. 2012; Roesler et al. 2002).

In the south Siberian soda lakes (Kulunda Steppe, Altai) (Fig. 1), where the salinity ranges from 50 to $400 \mathrm{~g} / \mathrm{l}$, the most common oxygenic phototrophic communities are represented either by floating aggregates of the green algae Ctenocladus and filamentous cyanobacteria or by filamentous cyanobacterial biofilms. The biofilms mainly contain haloalkaliphilic members of the genera Geitlerinema and Nodosilinea and, occasionally, Leptolyngbya. Members from the genera Arthrospira, which are dominant in equatorial soda lakes, are virtually absent in this area (O. Samylina, personal communication). At reduced salinity a mass development of heterocystous Anabaenopsis had been observed in East-African soda lakes (Krienitz et al. 2013).

Cyanobacteria are traditionally considered as the only diazotrophic component of the oxygenic phototrophic community (Fig. 3b2). However, as they are only moderately salt-tolerant, the identity and mechanisms of primary nitrogen fixation in hypersaline soda lakes remain enigmatic.

Anoxygenic phototrophs, represented by the haloalkaliphilic members of Chromatiales (Thiorhodospira, Thiorhodovibrio) at moderate salinity and Ectothiorhodospiracea (EctothiorhodospiralHalorhodospira) at high salinity, also contribute to the primary production in soda lakes (Gorlenko 2007; Kompantseva et al. 2009). 'Secondary' primary producers represented by aerobic chemolithoautotrophic bacteria also contribute to inorganic carbon fixation in soda lakes. Haloalkaliphilic representatives of nitrifying, sulfur-oxidizing, $\mathrm{H}_{2}$-oxidizing, and carboxydotrophic bacteria have recently been isolated from soda lakes and characterized (Sorokin and Kuenen 2005; Grant and Sorokin 2011).

\section{Heterotrophic carbon utilization}

The heterotrophic bacteria, responsible for the primary degradation of organic matter produced by the autotrophic bacteria, include aerobes and fermentative anaerobes, which in turn, are composed of two subgroups: the hydrolytics (Fig. 3a2), which degrade polymers, and the secondary heterotrophs ('dissipotrophs') (Figs. 3a4) that utilize the resulting monomers.

Aerobic hydrolytics, which produce alkali-stable hydrolases, have been the focus of many studies in the past, because of the high application potential of their enzymes in industry (Horikoshi 2004, 2006). However, only few of the known isolates were recovered from soda lakes. They mostly include aerobic Firmicutes, such as species within the genus Bacillus with various glycosidase activities and several Actinobacteria, such as Cellulomonas and Dietzia, and Gammaproteobacteria, such as the amylolytic Alkalimonas (Grant and Sorokin 2011). Recently, it was shown that aerobic haloalkaliphilic Actinobacteria and Gammaproteobacteria from the genus Marinimicrobium from soda lakes and soda soils can utilize chitin as growth substrate (Sorokin et al. 2012a). So far, only a single pure culture of an anaerobic low salt-tolerant cellulolytic bacterium has been recovered from a soda lake represented by Clostridium alkalicellum (Zhilina et al. 2005a). Two recently described fermentative anaerobic haloalkaliphiles from soda lakes can use pectin as substrate either at moderate (Natronoflexus pectinovorans from the Bacteriodetes) or high salt concentration (Natronovirga from the Clostridiales) (Sorokin et al. 2011a, 2012b) (Fig. 3a3). Additionally, two deep lineages of fermentative haloalkaliphilic bacteria specialized to exclusively utilize chitin as growth substrate were isolated from soda lakes. Both groups belong to the phylum TG3, which, until now, only included uncultured bacteria (Sorokin et al. 2012a). The high salt- 


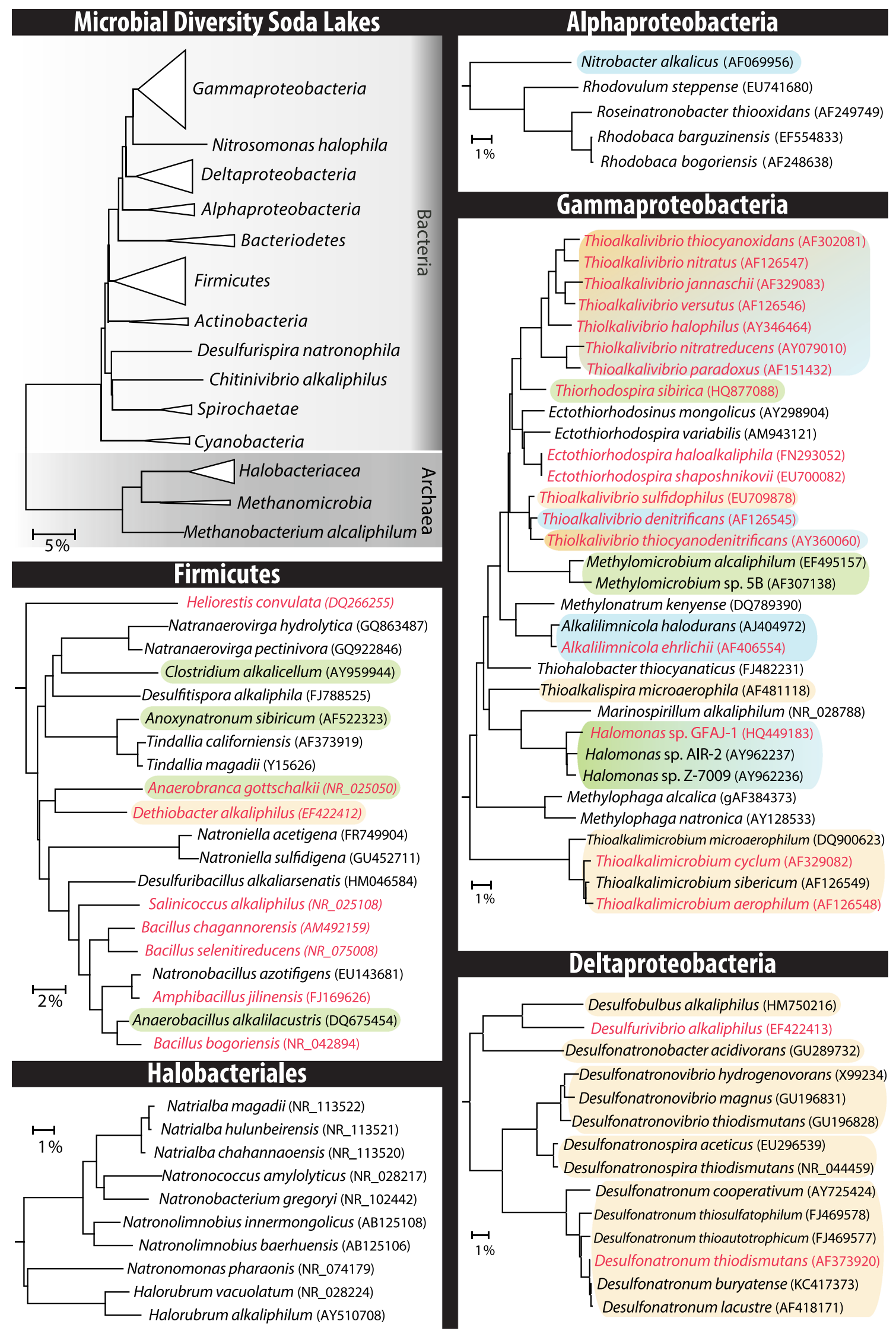


4Fig. 2 Phylogenetic tree of identified bacteria and archaea in soda lakes. Indicated are the cultured microbes whom have been shown to be active in biogeochemical cycling (green carbon cycle, blue nitrogen cycle, yellow sulfur cycle, see Fig. 3). The red font indicates that the genome of the strain has been sequenced

tolerant group has recently been described as Chitinivibrio alkaliphilus (Sorokin et al. 2014a).

Secondary ('dissipotrophic') heterotrophs, i.e., those that utilize monomeric organic compounds such as sugars, amino acids, organic acids, and alcohols are among the best represented groups of haloalkaliphiles isolated so far from soda lakes (Fig. 3a4). Among the aerobes, haloalkaliphilic members of the genus Halomonas from the Gammaproteobacteria, Bacillus from the Firmicutes, and Actinobacteria are the most abundant (Duckworth et al. 1996; Grant and Sorokin 2011). Soda lake fermentative anaerobes are dominated by haloalkaliphilic representatives of Clostridia, such as members of the genera Anoxynatronum, Anaerovirgula, Alkaliphilus, Natranaerobius, Natranaerobaculum, and certain species of Anaerobranca, Spirochaeta, and Anaerobacillus (Zavarzin et al. 1999; Zavarzin and Zhilina 2000; Bowers et al. 2009; Grant and Sorokin 2011; Mesbah and Wiegel 2012) (Fig. 3a5). Among the secondary anaerobes, which function during the last stage of organic carbon degradation, homoacetogens (Fig. 3a7) and methanogens (Fig. 3a6) represent the least studied functional groups of soda lake microbial communities. The genera Tindallia, Natronincola (Clostridiales), and Natroniella acetogena (Halanaerobiales) represent heterotrophic fermentative haloalkaliphilic acetogens, utilizing amino acids and alcohols as substrates (Kevbrin et al. 1998; Zhilina et al. 1995, 1998). Hydrogenotrophic acetogens in soda lakes have only recently been discovered. The only culturable organism is represented by a novel, extremely salt-tolerant haloalkaliphilic member of the Halanaerobiales described as Fuchsiella alkaliacetigena (Zhilina et al. 2012).

\section{Methane cycle}

The methane cycle has been explored in soda lakes as an important part of the microbial carbon cycle. Substantial efforts have been made to detect methanogenic activity in anaerobic sediments from North American and Central Asian soda lakes (Fig. 1). The results clearly demonstrated a dominance of methylotrophic methanogenesis and absence of acetoclastic processes, while the results concerning hydrogenotrophic methanogenesis were inconclusive (Oremland and Miller 1993; Namsaraev et al. 1999; Sorokin et al. 2004a; Nolla-Ardèvol et al. 2012). Some of the key haloalkaliphilic players in soda lake methanogenesis have been isolated in pure culture and described, including two groups of methylotrophs, such as
Methanolobus taylorii (moderate salinity) and Methanosalsum zhilinae (high salinity), and a highly salt-tolerant lithotroph Methanocalculus natronophilus (Mathrani et al. 1988; Oremland and Boone 1994; Kevbrin et al. 1997; Zhilina et al. 2013).

Aerobic methanotrophs in soda lakes are dominated by low salt-tolerant alkaliphiles from the Gammaproteobacterial genus Methylomicrobium (Sorokin et al. 2000; Trotsenko and Khmelenina 2002). Assuming that methanotrophic alkaliphiles cannot grow at salinities above $1.5 \mathrm{M}$ of total $\mathrm{Na}^{+}$, while methane production still occurs at these high salinity values, the methane cycle in hypersaline soda lakes may be incomplete, similar as in hypersaline chloride-sulfate lakes (Conrad et al. 1995).

The nitrogen cycle

Denitrification in soda lakes is performed by heterotrophs dominated by extremely salt-tolerant alkaliphilic representatives of the genus Halomonas (Shapovalova et al. 2009) and by several facultative anaerobic lithotrophs, such as representatives of the genus Thioalkalivibrio (see below) and the Alkalilimnicola-Alkalispirillum group of the Gammaproteobacteria (Sorokin et al. 2006; Hoeft et al. 2007) (Fig. 3b1). Whether dissimilatory ammonification competes with denitrification in soda lakes has not yet been resolved. So far, the alkaliphiles with this metabolism have only been found in bioreactors operating at high $\mathrm{pH}$, i.e., Desulfurispirillum alkaliphilum from the phylum Chrysiogenetes (Sorokin et al. 2007b) and Sulfurospirillum alkalitolerans from the Epsilonproteobacteria (Sorokin et al. 2013a).

Heterotrophic anaerobic fermentative haloalkaliphiles actively fix nitrogen in soda lakes and soda soils (Sorokin et al. 2008c) (Fig. 3b2). These organisms are represented by two groups of the Firmicutes: a moderate salt-tolerant Anaerobacillus diazotrophicus (reclassified from Bacillus alkalidiazotrophicus) (Sorokin et al. 2008d) and a highly salt-tolerant Natronobacillus azotifigans (Sorokin et al. 2008e). Furthermore, the microbial activity and presence of the nifH gene, encoding a nitrogenase, have also been detected in two other soda lake anaerobes: the ironreducing Geoalkalibacter ferrihydriticus (Zavarzina et al. 2006) and the cellulolytic Clostridium alkalicellulosi (Zhilina et al. 2005a). Additionally, the nifH gene has been detected in several soda lake anoxygenic phototroph representatives (Tourova et al. 2007), which indicates that anoxygenic phototrophs may also contribute to nitrogen fixation. Not much research has been conducted on nitrogen fixation in soda lakes at oxic conditions. However, a major suspect is a group of heterocystous low salt-tolerant alkaliphilic cyanobacteria from the Anabaena group (Anabaenopsis and Nodularia) (O. Samylina, personal communication). Nitrogen fixation activity has been 
(A)

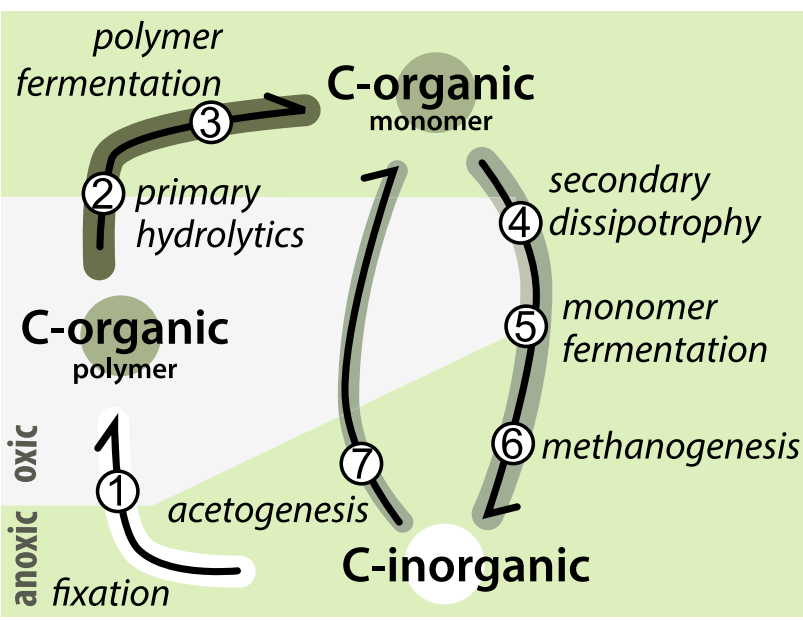

(B)

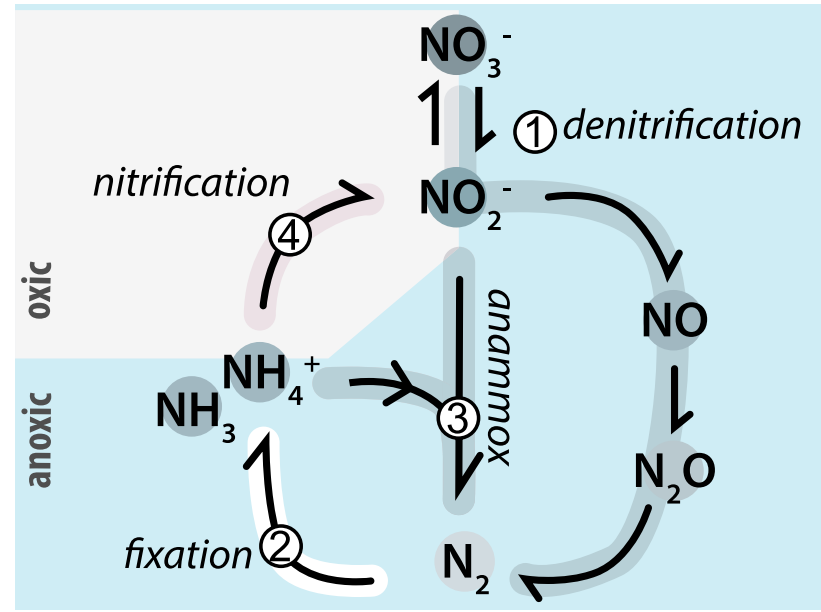

(C)

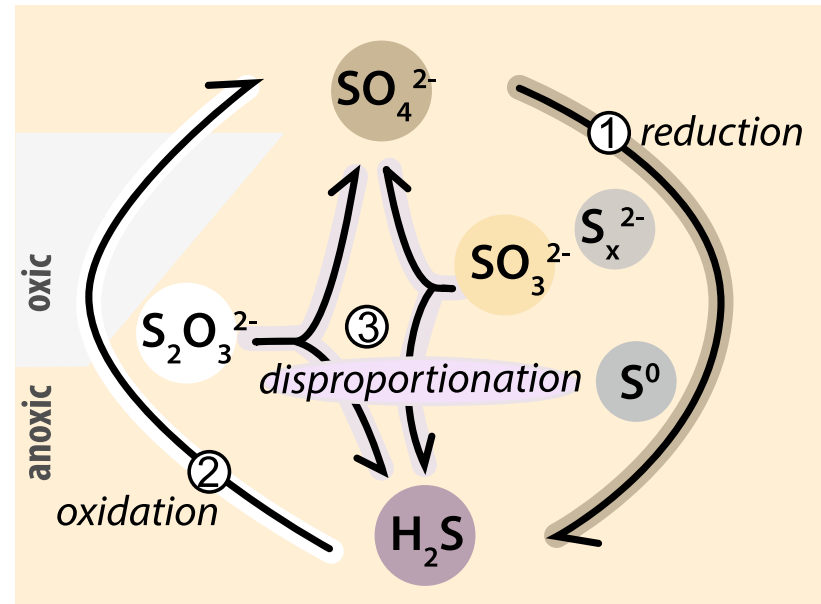

Fig. 3 Microbially mediated biogeochemical redox cycles in soda lakes. a The carbon cycle, $\mathbf{b}$ The nitrogen cycle, and $\mathbf{c}$ the sulfur cycle documented for aggregates of filamentous non-heterocystous Phormidium-like cyanobacteria and green algae belonging to the Ctenocladus in the oxic littoral zone of Mono Lake (Oremland 1990). However, it was not clear whether the phototrophic or the heterotrophic bacteria were responsible for the observed diazotrophy.

The ammonium produced during nitrogen fixation in soda lakes can be oxidized to nitrate via nitrite by haloalkaliphilic nitrifiers (Fig. 3b4). In soda lakes and soda soils ammonium oxidation to nitrite is performed by an extremely alkali-tolerant subpopulation of Nitrosomonas halophila, whilst nitrite oxidation can be performed by the moderately alkali-tolerant Nitrobacter alkalicus (Sorokin and Kuenen 2005). Since the maximum salt concentration for nitrification in soda lakes is $1 \mathrm{M}$ of total $\mathrm{Na}^{+}$(Sorokin 1998), the nitrogen cycle is inhibited in hypersaline soda lakes. In addition, the $\mathrm{NH}_{3} / \mathrm{NH}_{4}{ }^{+}$equilibrium at high $\mathrm{pH}$ favors the formation of toxic $\mathrm{NH}_{3}$ and, therefore, causes potential N-loss from the ecosystem (Tindall 1988; Sorokin and Kuenen 2005). Therefore, the nitrogen cycle in soda lakes, especially in hypersaline ones, may depend on an externally supplied source of $\mathrm{NO}_{x}^{-}$.

The sulfur cycle

\section{Sulfidogenesis}

The dissimilatory reduction of oxidized sulfur compounds such as sulfate, sulfite, thiosulfate, and sulfur, resulting in sulfide production (sulfidogenesis) are important biogeochemical processes within soda lakes (Sorokin et al. 2010a, 2011b) (Fig. 3c1). Several obligatory anaerobic and obligatory haloalkaliphilic bacteria can perform these reactions. Members of the deltaproteobacterial genera Desulfonatronum, Desulfonatronovibrio, and Desulfonatronospira represent lithotrophic sulfate-reducing bacteria (SRB) in soda lakes (Sorokin et al. 2011c). They can grow either as typical SRB by oxidizing hydrogen, formate or short-chain organic compounds as electron donor, and sulfate, thiosulfate or sulfite as electron acceptor, or they can obtain energy by thiosulfate or sulfite disproportionation (Sorokin et al. 2008a, 2011b). Heterotrophic SRB in soda lakes belong to the group of incomplete oxidizers, utilizing either propionate (Desulfobulbus alkaliphilus) or butyrate (Desulfobotulus alkaliphilus) as e-donor/C-source with sulfate or thiosulfate as e-acceptor and forming acetate as a final product (Sorokin et al. 2010b; Sorokin et al. 2012d). So far, only a single haloalkaliphilic SRB, described as Desulfonatronobacter acidivorans, has been found in soda lakes, which belongs to the complete oxidizers (Sorokin et al. 


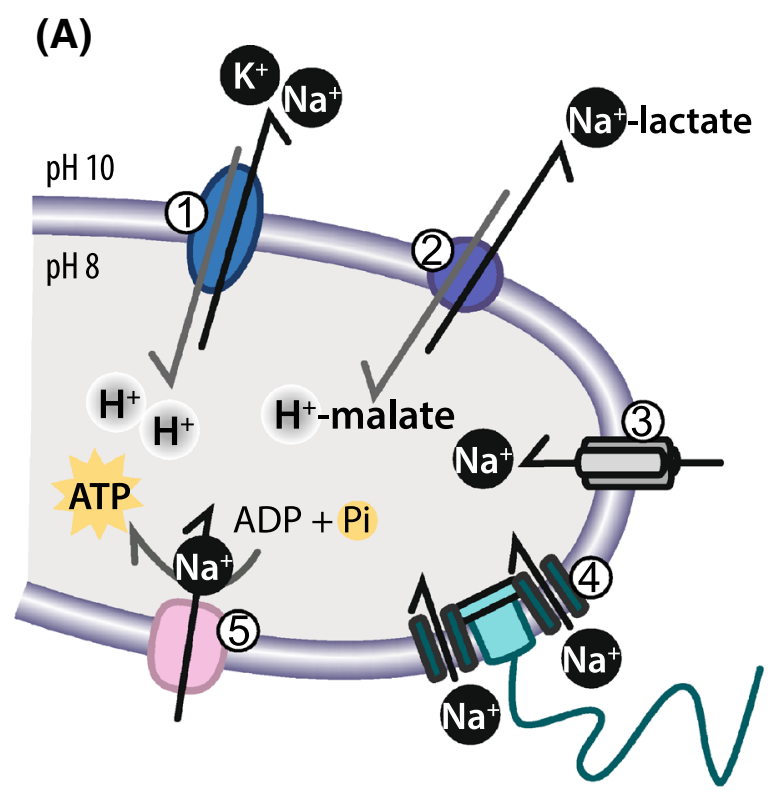

(B)
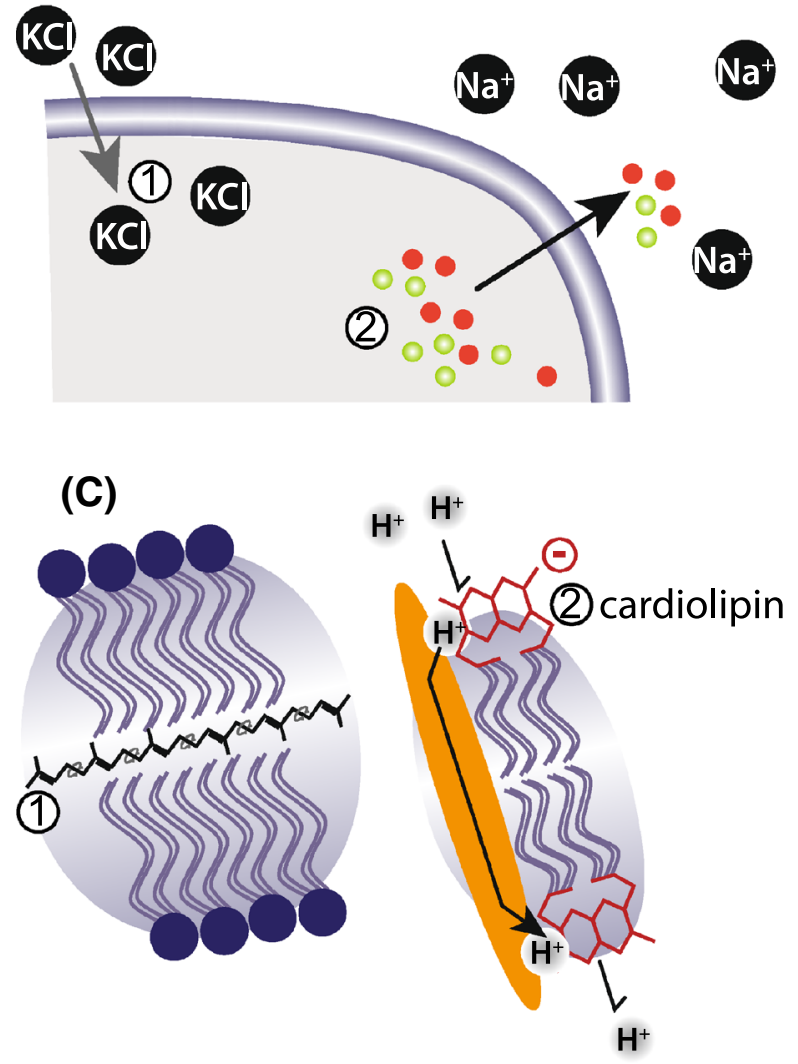

Fig. 4 Proposed adaptation strategies to the extreme haloalkaline environment. a Bioenergetic adaptations: 1 Electrogenic proton antiporters with $\mathrm{Na}^{+}$or $\mathrm{K}^{+} .2$ Electroneutral antiporters. 3 Voltagegated $\mathrm{Na}^{+}$channel. $4 \mathrm{Na}^{+}$-dependent flagella. $5 \mathrm{Na}^{+}$ATPase. b Osmoprotectants retain the osmotic pressure within the cell via the 1 Salt in cytoplasm strategy or 2 the synthesis or accumulation of osmoprotectants. c Structural membrane adaptations to survive the extreme haloalkaline conditions: 1 squalene or 2 cardiolipins 2012c). It can oxidize several volatile fatty acids (VFA) completely to $\mathrm{CO}_{2}$ with sulfate or thiosulfate as e-acceptor, but cannot utilize externally provided acetate. Haloalkaliphilic syntrophic associations of reverse acetogenic Clostridiales members and lithotrophic SRB drive acetate oxidation in soda lakes under sulfate-reducing conditions. At low salt concentrations the association includes "Candidatus Contubernalis alkalaceticum" and Desulfonatronum cooperativum (Zhilina et al. 2005b), whilst at extremely high salt concentrations the association contained "Candidatus Syntrophonatronum acetioxidans" and Desulfonatronospira sp. (Sorokin et al. 2014b).

Elemental sulfur reduction in soda lakes is probably not performed by SRB, since none of the pure cultures of haloalkaliphilic SRB can grow with sulfur as e-acceptor. Instead, three different lineages of obligatory anaerobic haloalkaliphiles are implicated in sulfur reduction. In all three, the actual e-acceptor is not sulfur itself, but polysulfide $\left(\mathrm{S}_{x}^{2-}\right)$ forming abiotically at high $\mathrm{pH}$ from sulfur and sulfide. The first, Desulfurispira natronophila, belongs to the phylum Chrysiogenetes (Sorokin and Muyzer 2010). The second group of sulfur/polysulfide-respiring haloalkaliphiles, belongs to the Firmicutes and was isolated from soda lakes with formate as e-donor. A moderately salttolerant representative is described as Desulfuribacillus alkaliarsenatis (Sorokin et al. 2012d). Apart from sulfur, it can also use arsenate and thiosulfate as e-acceptors. Third, at saturated soda concentrations, microbial-mediated sulfur reduction can also be performed by Natroniella sulfidigena, which belongs to the Halanaerobiales. It can use acetate, $\mathrm{H}_{2}$, and formate as e-donors for sulfur/polysulfide-dependent respiration (Sorokin et al. 2011d).

\section{Elemental sulfur disproportionation}

Two anaerobic low salt-tolerant alkaliphilic anaerobes from soda lakes, Dethiobacter alkaliphilus and Desulfurivibrio alkaliphilus, originally described as sulfur and thiosulfate reducers (Sorokin et al. 2008b), have the capability to grow chemolithoautotrophically by sulfur or polysulfide disproportionation (Fig. 3c3). Remarkably, they are the first alkaliphiles with such a physiology, and in contrast to the neutrophilic sulfur disproportionators, they do not require the presence of ferric iron to precipitate toxic sulfide compounds (Poser et al. 2013).

\section{Sulfur-oxidizers}

Sulfide produced by sulfidogens can be oxidized to elemental sulfur or sulfate by phototrophic and chemotrophic sulfur oxidizing bacteria (SOB) (Fig. 3c2). In soda lakes, the 


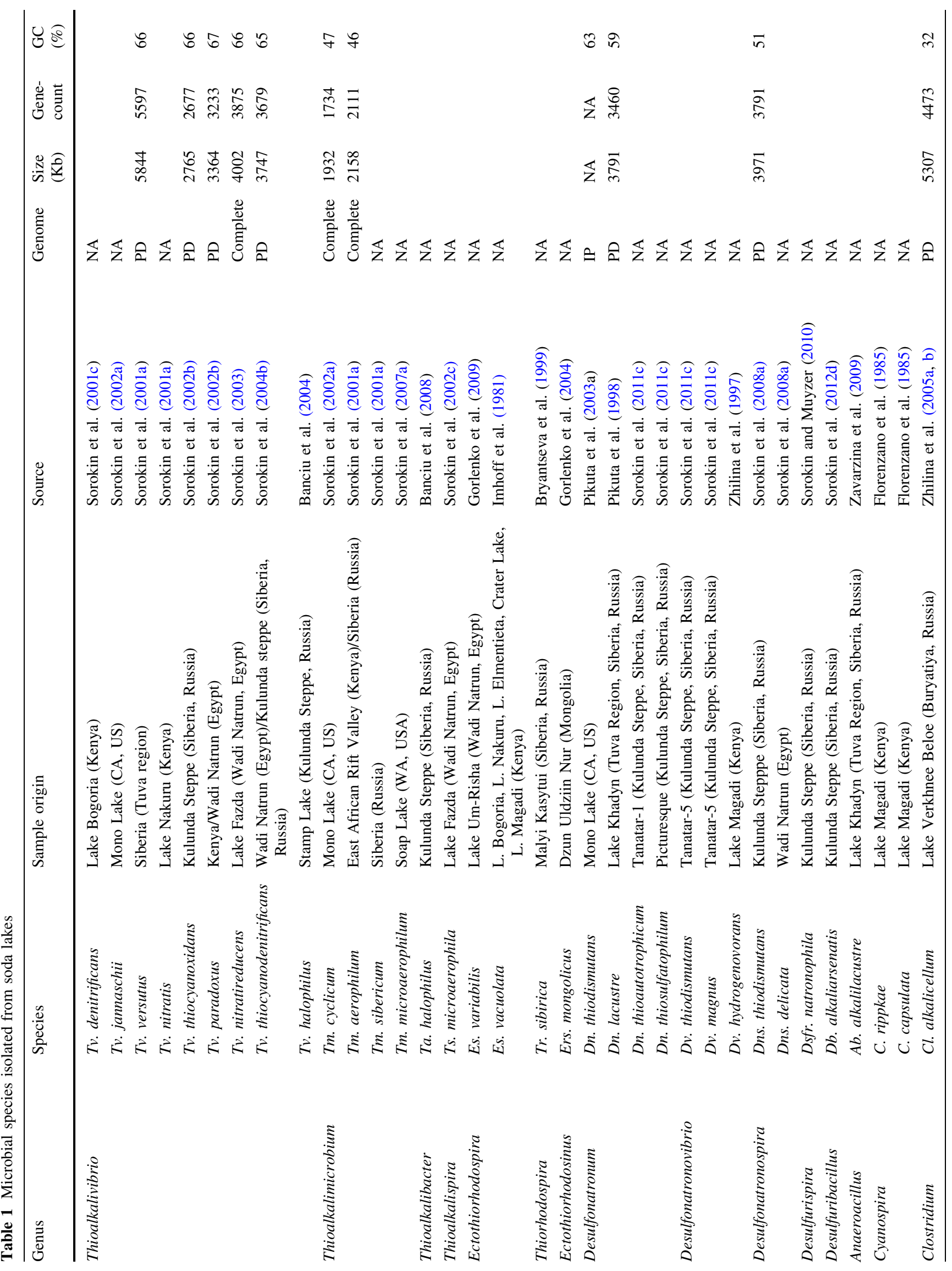




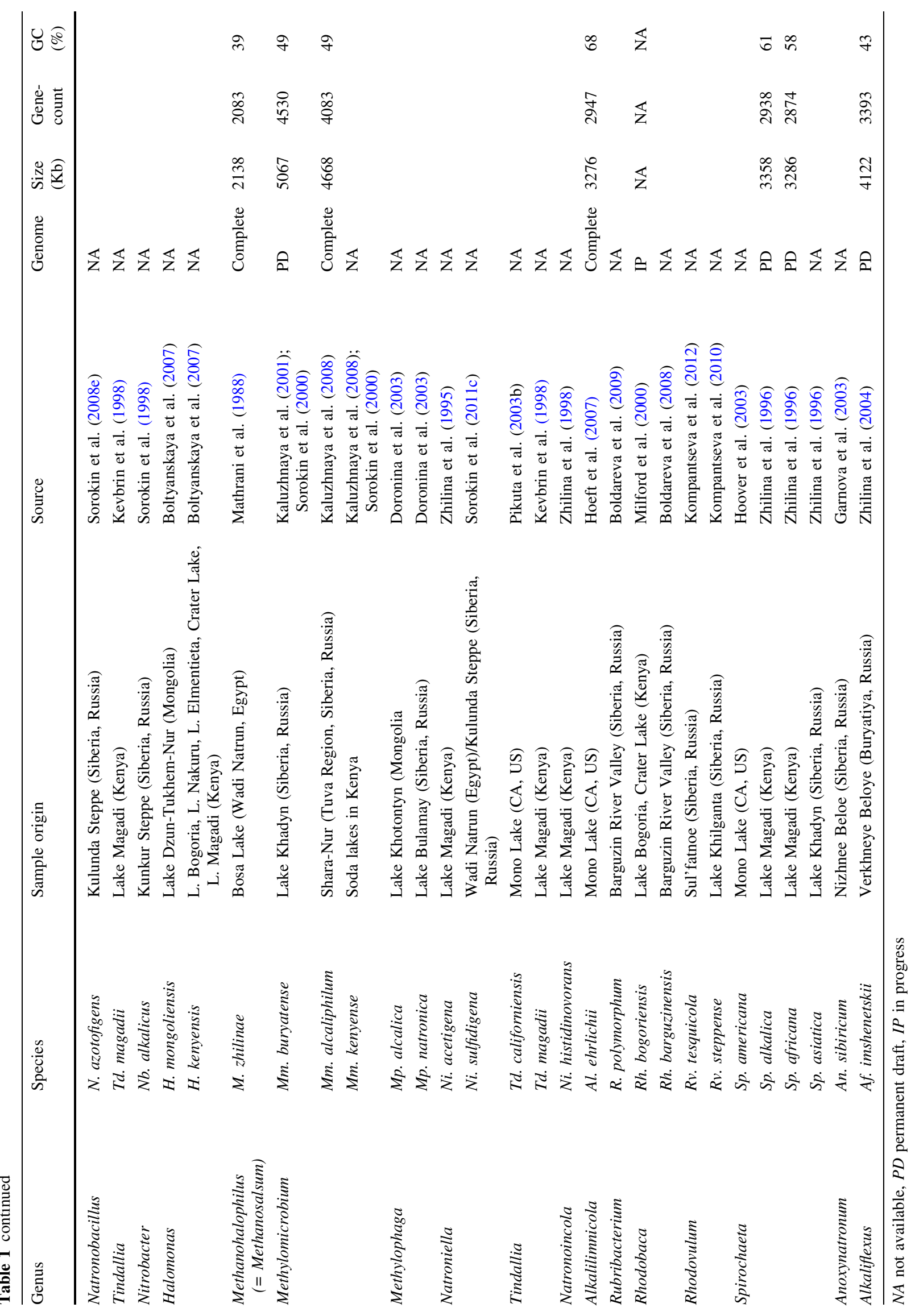


former are dominated by anoxygenic purple sulfur bacteria, including haloalkaliphilic members of the genera Ectothiorhodospira and Halorhodospira at high salinity, and members of the genera Thiorhodospira, Thioalkalicoccus, and Ectothiorhodosinus at low salinity (Imhoff and Trueper 1981; Gorlenko 2007). The chemotrophic SOB in soda lakes belong to 4 genera of the haloalkaliphilic Gammaproteobacteria: the genera Thioalkalimicrobium and Thioalkalispira are moderate salt-tolerant aerobic alkaliphiles, while the genera Thioalkalivibrio and Thioalkalibacter can grow in salt concentrations reaching saturation (Sorokin et al. 2013b). They are obligate autotrophs and utilize reduced sulfur compounds, including sulfide, polysulfide, thiosulfate, polythionates, and elemental sulfur as e-donor (Sorokin et al. 2001b, c, 2002b, 2003; Banciu et al. 2004) The genus Thioalkalivibrio is the most metabolically flexible and tolerates a wide range of salinity values. Several Thioalkalivibrio species have the ability to grow anaerobically with $\mathrm{NO}_{x}^{-}$as e-acceptors (Fig. 3b1), such as Tv. denitrificans (Sorokin et al. 2001b), Tv. nitratireducens (Sorokin et al. 2003), and Tv. thiocyanodenitrificans (Sorokin et al. 2004b).

Other Thioalkalivibrio species such as Tv. thiocyanoxidans, Tv. paradoxus, and Tv. thiocyanodenitrificans, are capable of growth using thiocyanate as the sole energy, sulfur, and nitrogen source (Sorokin et al. 2001c, 2002b, 2004b). The first two species degrade thiocyanate primarily to cyanate and were the first SOB cultures for which the cyanate pathway of primary thiocyanate degradation has been shown.

\section{Prokaryotic diversity, activity, and community structure identified by cultivation-independent approaches}

It is well recognized that from the majority of the microorganisms in nature, cultured isolates are yet to be obtained. Alternative cultivation-independent approaches, especially those based on the characterization of DNA, have proven to be very useful in expanding the known diversity of the microbial communities thriving under the extreme conditions of high salinity and high $\mathrm{pH}$. Grant et al. (1999) were the first to use molecular methods to study the archaeal diversity of saturated alkaline brines in Lake Magadi (Kenya, Africa) (Fig. 1). Thereafter, the presence of novel prokaryotic phylotypes in various soda lakes was shown by cloning and/or denaturing gradient gel electrophoresis (DGGE) of 16S rRNA gene fragments (Ochsenreiter et al. 2002; Rees et al. 2004; Ma et al. 2004; Mesbah et al. 2007). More recently, next-generation sequencing of PCR-amplified regions of the 16S rRNA gene and reversed transcribed mRNA have been used (Lanzen et al. 2013).
Cultivation-independent approaches have also greatly improved our understanding of the overall microbial community structure and functioning in soda lakes, which seems to be governed by the prevailing salt concentrations. There is some evidence that hypersaline soda lake brines (total salinity $>250 \mathrm{~g} / \mathrm{L}$ ) harbor similar microbial communities to hypersaline solar saltern brines of neutral $\mathrm{pH}$. The latter are characterized by a low diversity dominated by a few extremely halophilic archaea, belonging to the class Halobacteria within the phylum Euryarchaeota (Rodriguez-Valera et al. 1985; Oren 1994; Casamayor et al. 2002; Ghai et al. 2011). It is conceivable that hypersaline soda lake brines may also be dominated by such archaea, as evidenced by the failure to amplify bacterial 16S rRNA genes from the soda brines (Grant et al. 1999) and the clear dominance of euryarchaeal sequences in 16S rRNA gene libraries (Grant et al. 1999; Ochsenreiter et al. 2002; Mesbah et al. 2007). The latter sequences share a high similarity with members from the family Halobacteriaceae (class Halobacteria; Ochsenreiter et al. 2002; Mesbah et al. 2007) and from halophilic members of the order Methanosarcinales (class Methanomicrobia) (Mesbah et al. 2007).

Moderately saline soda lake brines (total salinity between 50 and $250 \mathrm{~g} / \mathrm{L}$ ) harbor more diverse microbial communities than hypersaline environments and the community composition is affected by lake stratification and prevailing oxygen concentrations (Dimitriu et al. 2008; Carini and Joye 2008). The total bacterial and archaeal diversity in low saline lakes (total salinity between 35 and $50 \mathrm{~g} / \mathrm{L}$ ) can be as high as that in fresh water lakes (Lanzen et al. 2013). Several studies on the bacterioplankton from low and moderate saline soda lakes showed the dominant presence of Alphaproteobacteria (mostly from the family Rhodobacteraceae) and Gammaproteobacteria (including the genera Halomonas and Thioalkalivibrio), Firmicutes (aerobic Bacillus, anaerobic Clostridia), Bacteroidetes (Cytophaga, Flexibacter, Flavobacterium, Bacteroides, Salinibacter), the cyanobacterial genera Arthrospira and Anabaenopsis, and several purple phototrophic bacteria belonging to the families of Ectothiorhodospiraceae, Chromatiaceae and Rhodobacteraceae (Humayoun et al. 2003; Dimitriu et al. 2008; Mesbah et al. 2007; Pagaling et al. 2009; Lanzen et al. 2013; Dadheech et al. 2013; Asao et al. 2011).

The salt concentration in the sedimentary pore water of soda lakes also has a strong influence on the in situ microbial community composition (Mesbah et al. 2007) and negatively affects the diversity (Kulp et al. 2007; Foti et al. 2008). In addition, some of the fundamental biogeochemical cycles are hampered through the inhibition of key catabolic transformations, such as denitrification, sulfate reduction, and methanogenesis (Kulp et al. 2007; 
Sorokin et al. 2010a). Nevertheless, bacterial 16S rRNA from clone libraries and DGGE bands from moderate and hypersaline soda lake sediments was found to be relatively diverse, including various Alphaproteobacteria from the order Rhodobacterales or related to the genus Brevundimonas; Firmicutes (mainly Clostridia), Gammaproteobacteria, Bacteroidetes, Betaproteobacteria (genera Alcaligenes and Comamonas), Deltaproteobacteria (orders Desulfovibrionales and Desulfobacterales), Actinobacteria (moderate salinities), and benthic cyanobacteria (Mesbah et al. 2007; Ma et al. 2004; Foti et al. 2008; Dimitriu et al. 2008; Kulp et al. 2006).

Molecular studies targeting functional genes are necessary to identify possible microbial-mediated processes within the biogeochemical element cycles (Fig. 3). Giri et al. (2004) were the first to use $c b b L / M$ genes, encoding the large subunit of RuBisCo form I/II (Watson and Tabita 1997), as a functional and phylogenetic marker for autotrophs in soda lakes. They studied the distribution of these genes along a redox gradient in the sediment of Mono Lake (USA).

To study the diversity of autotrophic bacteria in soda lake sediments from the Kulunda Steppe (Siberia, Russia) and Wadi Natrun (Egypt) (Fig. 1), Kovaleva and colleagues (Kovaleva et al. 2011) used $a c l B$, which encodes the large subunit of ATP citrate lyase part of the reverse Krebs cycle, in addition to $c b b L / M$ (Campbell et al. 2003). Overall, most autotrophs in the studied soda lake sediments use the Calvin-Benson-Bassham cycle for inorganic carbon fixation, with RuBisCO form I as the dominant and most diverse type. More specifically, the autotrophs in the sediments of hypersaline soda lakes were primarily composed of cyanobacteria and haloalkaliphilic SOB from the family Ectothiorhodospiraceae (class Gammaproteobacteria, order Chromatiales), including the chemolithotrophic genus Thioalkalivibrio and the phototrophic genus Halorhodospira (Giri et al. 2004; Kovaleva et al. 2011). In the less saline lakes, distinct novel lineages of anoxygenic phototrophs with RuBisCO form I within the order Chromatiales were found (Kovaleva et al. 2011). Autotrophic nitrification in Mono Lake was studied via bacterial and archaeal amoA and 16S rRNA gene libraries (Carini and Joye 2008). Samples were taken after an extended period of meromixis during which significant nitrification was measured and the mixoliminion was presumed to have become chronically N-deprived (Joye et al. 1999; Carini and Joye 2008). Ammonia monooxygenase catalyzes the first step in aerobe ammonium oxidation by autotrophic nitrifiers, and $a m o A$, encoding its active-site polypeptide, is frequently used as a functional marker (Junier et al. 2010).

Sequences obtained from ammonia-oxidizing bacteria (AOB) were most closely related to halo- and/or alkalitolerant Nitrosomonas-like sequences. Additionally, FISH analysis revealed the presence of Crenarchaeota and the correlation of nitrification rates with crenarchaeal numbers. Although no archaeal amoA sequences were detected, it cannot be ruled out that ammonia-oxidizing archaea (AOA) contribute significantly to nitrification in Mono Lake (Carini and Joye 2008). Key functional genes of dissimilatory SRB are $d s r \mathrm{AB}$, which encodes the $\alpha$ - and $\beta$ subunits of a dissimilatory sulfite reductase, and aps A, which encodes the $\alpha$-subunit of an APS reductase (Wagner et al. 2005). Two independent studies focusing on these genes in sediment samples and enrichment cultures from Mono Lake (USA; Scholten et al. 2005) and soda lakes in Siberia (Russia; Foti et al. 2007) revealed novel clusters of SRB affiliated to the deltaproteobacterial order Desulfovibrionales and the family Desulfobacteraceae within the order Desulfobacterales. The latter comprises all of the known SRB that oxidize acetate completely during sulfate reduction. In combination with high $d s r B$ copy numbers per cell and sulfate reduction rates encountered even in soda lakes with more than $475 \mathrm{~g} / \mathrm{L}$, Foti et al. (2007) challenged an earlier hypothesis, specifically for the case of soda lakes, that complete carbon oxidizers could only grow at salt concentrations below $150 \mathrm{~g} / \mathrm{L}$ (Oren, 1999 and Oren 2011).So far, no acetate-oxidizing SRB have been isolated from soda lakes, even at low salinity.

The oxidative part of the sedimentary sulfur cycle was also studied in various soda lakes from Siberia and Egypt (Tourova et al. 2013) by targeting $\operatorname{soxB}$, which encodes an indispensible sulfate thiohydrolase in the Sox pathway proposed for the oxidation of thiosulfate in SOB (Ghosh and Dam 2009). The majority of detected SOB sequences belonged to autotrophic Gammaproteobacteria, including the genus Thioalkalivibrio from which already many cultured isolates have been obtained. Interestingly, uncultured putative heterotrophic SOB from the Gamma-and Alphaproteobacterial classes have been found by comparing sox $B$ clone libraries (Tourova et al. 2013) with earlier constructed $c b b L / M$ genes from the same sediment samples (Kovaleva et al. 2011).

A very effective technique to study microbial activity is the use of stable isotope probing (SIP; Dumont and Murrell 2005). Lin et al. (2004) used this approach to identify active methanotrophs in sediments of a low saline Transbaikal soda lake. By targeting both 16S rRNA genes as well as genes encoding pmoA and mmoX, key enzymes in the aerobic methane oxidation pathway (McDonald et al. 2008), they found that the type 1 methanotrophs, belonging to the gammaproteobacterial genera Methylomicrobium and Methylobacter, were the main methane oxidizers. Active aerobic methane oxidation, as well as archaeal ammonium oxidation (ammonium oxidation to nitrite) and denitrification (nitrite reduction to nitrous oxide) in the water column of two low saline Ethiopian soda lakes was 
also shown by the successful amplification of mRNA for particulate methane monooxygenase (lake Beseka), ammonia monooxygenase (amoA) and nitrite reductase (nirK; lake Arenguadi; Lanzen et al. 2013).

\section{Cellular adaptations to high salt concentrations and high $\mathrm{pH}$ values}

Haloalkaliphilic bacteria have developed essential strategies to adapt to the extreme haloalkaline conditions in soda lakes (Padan et al. 2005; Slonczewski et al. 2009). Although not much is known about the genetics of these adaptations, some bioenergetic and structural adjustments that ensure the maintenance of an intracellular neutral $\mathrm{pH}$ and osmotic pressure have mainly been described in the species Bacillus halodurans $\mathrm{C} 125$ and B. pseudofirmus OF4 (Kitada et al. 1994; Ito et al. 2004; Janto et al. 2011). The membrane structure of alkaliphiles remains stable over a wide range of $\mathrm{pH}$ and salinity values and is poorly permeable to protons and sodium ions (van de Vossenberg et al. 1999). Therefore, these microbes use transporter proteins to mediate the transmembrane $\mathrm{pH}$ gradient $(\Delta \mathrm{pH})$ and electric potential $(\Delta \Psi)$. The intracellular $\mathrm{pH}$ is regulated by several transporter mechanisms, one of which is mediated by electrogenic antiporters that import protons to the cytoplasm, whilst exporting a counterbalancing monovalent cation: $\mathrm{Na}^{+}$or $\mathrm{K}^{+}$(Ito et al. 1997; Kitada et al. 1994; Hunte et al. 2005; Mesbah et al. 2009; Muyzer et al. 2011, 2012) (Fig. 4a1). It has been shown that Escherichia coli cells require a Na+$: \mathrm{H}^{+}$exchange ratio of at least $1: 2$ to support growth in alkaline environments (Pinner et al. 1993); however, the coupling stoichiometry of alkaliphiles isolated from soda lakes has so far not been determined yet. An alternative electro-neutral proton transporter has been described in B. subtilis. It functions in carrying protonbound malate into the cell whilst cytoplasmic sodiumbound lactate is exported (Wei et al. 2000) (Fig. 4a2). Whether this transporter plays a potential role in the $\mathrm{pH}$ homeostasis of haloalkaliphiles remains to be elucidated. Another group of sodium transporters that are thought to play a role in $\mathrm{pH}$ homeostasis and also in motility and chemotaxis under alkaline conditions is the voltage-gated $\mathrm{Na}^{+}$channel, encoded by $n c b A$ in $B$. pseudofirmus OF4, (Ito et al. 2004; Fujinami et al. 2007) (Fig. 4a3). These channels can be co-localized with methylated chemotaxis proteins (Fujinami et al. 2007). Chemotaxis is also mediated through motility, which is sodium dependent in $B$. pseudofirmus (Ito et al. 2005; Fujinami et al. 2009) (Fig. 4a4). In the absence of sodium, potassium or rubidium can replace the role of sodium (Terahara et al. 2012). Last, an ATPase driven by a sodium motive force instead of a proton motive force has been identified in extremely salt-tolerant alkaliphilic clostridia Natranaerobius (Mesbah and Wiegel 2011) (Fig. 4a5). Although such a protein has not yet been discovered in haloalkaliphiles, it is conceivable that they may possess a similar mechanism, which utilizes the excess sodium and maintains a high transmembrane electric potential.

The high salinity in soda lakes also causes a high degree of osmotic stress to haloalkaliphiles, requiring them to synthesize osmoprotectants. In order to retain turgor pressure, halophilic microorganisms are known to either use the "salt in cytoplasm" strategy, where intracellular $\mathrm{KCl}$ concentrations are kept higher than the extracellular concentrations (Fig. 4b1), or to synthesize or accumulate compatible solutes during which high concentrations of neutral soluble organic molecules are stored in the cytoplasm (Rössler and Müller 2001) (Fig. 4b2). The compounds glycine betaine, glutamine, proline, ectoine, and hydroxyectoine have been found to play major roles as compatible solutes in bacteria (Grammann et al. 2002; Banciu et al. 2005; Hoffmann et al. 2012; Sorokin et al. 2013b). Extremely halo(alkali)philic Euryarchaeota predominantly utilize $\mathrm{K}^{+}$as an osmotic regulator (Oren 1999, 2011). These osmolytes do not play an active role in the metabolism of the cell, but are pivotal to the cellular volume and homeostasis (Levy-Sakin et al. 2014), and have been shown to stabilize membrane protein structures (Burg and Ferraris 2008; Roychoudhury et al. 2013). Although the "salt out" strategy of osmotic regulation is energetically more expensive than the "salt in" strategy, it allows microorganisms with a highly efficient energy metabolism to survive over larger salinity gradients (Oren 2011).

Structural adjustments within the cell membrane of haloalkaliphilic prokaryotes include an increased level of the neutral lipid squalene and the polar lipid cardiolipin in the phospholipid bilayer (Angelini et al. 2012). Squalene has also been found in the lipid bilayer membrane of the bacterium Thioalkalivibrio versutus strain ALJ 15. Squalene functions in combination with cyclopropane fatty acids in the maintenance of their cellular membrane and might prevent proton leakage (Banciu et al. 2005). Squalene is physically positioned in the center of the membrane, perpendicular to the two lipid layers that comprise the membrane (Hauss et al. 2002) (Fig. 4c1). Another class of lipids found in bacterial membranes (Thioalkalivibrio) is cardiolipin (Banciu et al. 2005), whose negative charge prevents protons from diffusing away from the cells (Haines and Dencher 2002) (Fig. 4c2). The membrane lipids of extremely halophilic Euryarchaea contain a large amount of diacidic phospholipids (Tenchov et al. 2006). Some extremely halophilic prokaryotes, such as memebrs of the Halobacteriaceae and Salinibacter, have membrane surface layers that are strongly enriched in acidic amino acids (Oren 2013). The proteins may enable the bacteria to 
influence the co-ordination of water molecules on their surface membranes facilitating their solubility at higher salt concentrations (Talon et al. 2014). Ecophysiological experiments followed by transcriptome and proteome analyses will offer an opportunity to provide additional insight into the molecular mechanisms by which these organisms adapt to extreme conditions of high $\mathrm{pH}$ and salinity.

\section{Perspectives}

Traditionally, studies on microbial communities were restricted to a few cultured isolates, whilst modern highthroughput techniques now allow the study of microbial community composition as a whole. Although a considerable number of cultured isolates has already been obtained from soda lakes, culture-independent methods have uncovered a much more diverse microbial community. Future studies should attempt to isolate members of the uncultured community (Alain and Querellou 2009). Metaomic approaches might help to facilitate the isolation of microbes by providing insight into potential metabolisms, such as for the isolation of the ammonium-oxidizing archaeon Nitrosopumilus maritimus (Könneke et al. 2005). Amplicon sequencing of 16S rRNA gene fragments followed by co-occurrence analysis might shed light onto the different interactions of the community members (Barberán et al. 2012). The detection of functional genes and their transcripts might reveal additional diversity and potential niche differentiation.

Metagenomics can be applied to obtain a high-resolution genetic inventory of the microbial community in soda lakes. Such a genetic inventory can be used to explore the overall metabolic capacity of the prokaryotic soda lake communities. Other high-throughput techniques monitor community-wide levels of gene-expression (meta-transcriptomics; Carvalhais et al. 2012), protein abundance (metaproteomics; Verberkmoes et al. 2009), and metabolite abundance (meta-metabolomics), thereby generating data to facilitate systems biology approaches.

Several metabolic processes might be present in soda lakes but have not yet been detected, such as anaerobic methane oxidation and anaerobic ammonium-oxidation. Furthermore, the importance of anaerobic polymer degradation in sediments is not well understood and the contribution of anoxygenic photosynthesis to primary production might be underestimated. Nitrogen fixation at hypersaline conditions is suspected to be limited to diazotrophic anoxygenic phototrophs and heterotrophs, but a comprehensive study targeting nifH and nifD genes in soda lakes, and distinguishing between the contribution of heterotrophs and primary producing phototrophs, is still lacking. Single cell techniques, like FISH-NanoSIMS (Dekas and Orphan 2011), may provide clear answers here. The effect of salinity on other reactions in the nitrogen cycle, such as nitrification, could be confirmed by focusing on the detection and quantification of amoA genes and their transcripts.

In conclusion, several questions regarding biogeochemical cycles in soda lakes are still open. To obtain a more comprehensive insight into the microbial diversity of soda lakes, its role in biogeochemical cycles and the molecular mechanisms by which the microorganisms adapt to the extreme environmental conditions, we have to study these habitats with a systems biology approach in which we combine novel isolation methods with state-of-the-art meta-omics techniques, and eventually with mathematical modeling to predict the response of cells and communities to environmental stimuli and to infer the interactions of coexisting populations.

Acknowledgments We would like to extend our thanks to our funding sources; Gerard Muyzer, Tom Berben, Emily D. Melton, Lex Overmars and Charlotte D. Vavourakis are supported by the ERC Advanced Grant PARASOL (No. 322551). Dimitry Sorokin is supported by the RBFR Grant 13-04-00049. Thanks also to Sacha Heath for the photograph of Mono Lake in Fig. 1.

Open Access This article is distributed under the terms of the Creative Commons Attribution License which permits any use, distribution, and reproduction in any medium, provided the original author(s) and the source are credited.

\section{References}

Alain K, Querellou J (2009) Cultivating the uncultured: limits, advances and future challenges. Extremophiles 13:583-594

Angelini R, Corral P, Lopalco P, Ventosa A, Corcelli A (2012) Novel ether lipid cardiolipins in archaeal membranes of extreme haloalkaliphiles. Biochim Biophys Acta 1818:1365-1373

Asao M, Pinkart HC, Madigan MT (2011) Diversity of extremophilic purple phototrophic bacteria in Soap Lake, a central Washington (USA) soda lake. Environ Microbiol 13:2146-2157

Ballot A, Kotut K, Novelo E, Krienitz L (2009) Changes of phytoplankton communities in Lakes Naivasha and Oloidien, examples of degradation and salinization of lakes in the Kenyan Rift Valley. Hydrobiologia 632:359-363

Banciu HL, Sorokin DY (2013) Adaptation in haloalkaliphiles and natronophilic bacteria. Polyextremophiles. Springer, Netherlands, pp 121-178

Banciu H, Sorokin DY, Galinski EA, Muyzer G, Kleerebezem R, Kuenen JG (2004) Thialkalivibrio halophilus sp. nov., a novel obligately chemolithoautotrophic, facultatively alkaliphilic, and extremely salt-tolerant, sulfur-oxidizing bacterium from a hypersaline alkaline lake. Extremophiles 8:325-334

Banciu H, Sorokin DY, Rijpstra WIC, Damsté JS, Galinski EA, Takaichi S, Muyzer G, Kuenen JG (2005) Fatty acid, compatible solute and pigment composition of obligately chemolithoautotrophic alkaliphilic sulfur-oxidizing bacteria from soda lakes. FEMS Microbiol Lett 243:181-187

Banciu HL, Sorokin DY Tourova TP, Galinski EA, Muntyan MS, Kuenen JG, Muyzer G (2008) Influence of salts and pH on growth and activity of a novel facultatively alkaliphilic, 
extremely salt-tolerant, obligately chemolithoautotrophic sufuroxidizing Gammaproteobacterium Thioalkalibacter halophilus gen. nov., sp. nov. from South-Western Siberian soda lakes. Extremophiles 12:391-404

Barberán A, Baters ST, Casamayor EO, Fierer N (2012) Using network analysis to explore co-ocurrence patterns in soil microbial communities. ISMEJ 6:343-351

Boldareva EN, Akimov VN, Boychenko VA, Stadnichuk IN, Moskalenko AA, Makhneva ZK, Gorlenko VM (2008) Rhodobaca barguzinensis sp nov., a new alkaliphilic purple nonsulfur bacterium isolated from a soda lake of the Barguzin Valley (Buryat Republic, Eastern Siberia). Microbiology (Moscow, English translation) 77:206-218

Boldareva EN, Moskalenko AA, Makhneva ZK, Tourova TP, Kolganova TV, Gorlenko VM (2009) Rubribacterium polymorphum gen. nov., sp nov., a novel alkaliphilic nonsulfur purple bacterium from an Eastern Siberian soda lake. Microbiology (Moscow, English translation) 78:732-740

Boltyanskaya YuV, Kevbrin VV, Lysenko AM, Kolganova TV, Tourova TP, Osipov GA, Zhilina TN (2007) Halomonas mongoliensis sp. nov. and Halomonas kenyensis sp. nov., new haloalkaliphilic denitrifiers capable of $\mathrm{N} 2 \mathrm{O}$ reduction, isolated from soda lakes. Microbiology (Moscow, English translation) 76:739-747

Bowers KJ, Mesbah NM, Wiegel J (2009) Biodiversity of polyextremophilic Bacteria: does combining the extremes of high salt, alkaline $\mathrm{pH}$ and elevated temperature approach a physicochemical boundary for life? Saline Syst 5:9

Bryantseva I, Gorlenko VM, Kompantseva EI, Imhoff JF, Süling J, Mityushina L (1999) Thiorhodospira sibirica gen. nov., sp. nov., a new alkaliphilic purple sulfur bacterium from a Siberian soda lake. Int J Syst Bacteriol 49:697-703

Burg MB, Ferraris JD (2008) Intracellular organic osmolytes: function and regulation. J Biol Chem 283:7309-7313

Campbell BJ, Stein JL, Cary SC (2003) Evidence of chemolithoautotrophy in the bacterial community associated with Alvinella pompejana, a hydrothermal vent polychaete. Appl Environ Microbiol 69:5070-5078

Carini SA, Joye SB (2008) Nitrification in Mono Lake, California: Activity and community composition during contrasting hydrological regimes. Limnol Oceanogr 53:2546

Carvalhais LC, Dennis PG, Tyson GW, Schenk PM (2012) Application of metatranscriptomics to soil environments. J Microbiol Meth 91:246-251

Casamayor EO, Massana R, Benlloch S, Øvreås L, Díez B, Goddard VJ, Gasol JM, Joint I, Rodríguez-Valera F, Pedrós-Alió C (2002) Changes in archaeal, bacterial and eukaryal assemblages along a salinity gradient by comparison of genetic fingerprinting methods in a multipond solar saltern. Environ Microbiol 4:338-348

Conrad R, Frenzel P, Cohen Y (1995) Methane emission from hypersaline microbial mats: lack of aerobic methane oxidation activity. FEMS Microbiol Ecol 16:297-306

Dadheech PK, Glöckner G, Casper P, Kotut K, Mazzoni CJ, Mbedi S, Krienitz L (2013) Cyanobacterial diversity in the hot spring, pelagic and benthic habitats of a tropical soda lake. FEMS Microbiol Ecol 85:389-401

De Graaff M, Bijmans MF, Abbas B, Euverink GJ, Muyzer G, Janssen AJ (2011) Biological treatment of refinery spent caustics under halo-alkaline conditions. Bioresour Technol 102:7257-7264

Dekas AE, Orphan VJ (2011) Identification of diazothrophic microorganisms in marine sediment via fluorescence in situ hybridization coupled to nanoscale secondary ion mass spectrometry (FISH-NanoSIMS). Meth Enzymol 486:282-305

Dimitriu PA, Pinkart HC, Peyton BM, Mormile MR (2008) Spatial and temporal patterns in the microbial diversity of a meromictic soda lake in Washington state. Appl Environ Microbiol 74(15): $4877-4888$

Doronina NV, Darmaeva TD, Trotsenko YA (2003) Methylophaga alcalica sp. nov., a novel alkaliphilic and moderately halophilic, obligately methylotrophic bacterium from an East Mongolian saline soda lake. Int J Syst Evol Microbiol 53:223-229

Dubinin AV, Gerasimenko LM, Zavarzin GA (1995) Ecophysiology and diversity of cyanobacteria in lake Magadi. Microbiology 64:845-849

Duckworth AW, Grant WD, Jones BE, van Steenburgen R (1996) Phylogenetic diversity of soda lake alkaliphiles. FEMS Microbiol Ecol 9:181-191

Dumont MG, Murrell JC (2005) Stable isotope probing-linking microbial identity to function. Nature Rev Microbiol 3:499-504

Florenzano G, Sili C, Pelosi E, Vincenzini M (1985) Cyanospira rippkae and Cyanospira capsulata (gen. nov. and spp. nov.): new filamentous heterocystous cyanobacteria from Magadi lake (Kenya). Arch Microbiol 140:301-306

Foti M, Sorokin DY, Lomans B, Mussman M, Zacharova EE, Pimenov NV et al (2007) Diversity, activity, and abundance of sulfate-reducing bacteria in saline and hypersaline soda lakes. Appl Environ Microbiol 73:2093-2100

Foti MJ, Sorokin DY, Zacharova EE, Pimenov NV, Kuenen JG, Muyzer G (2008) Bacterial diversity and activity along a salinity gradient in soda lakes of the Kulunda steppe (Altai, Russia). Extremophiles 12:133-145

Fujinami S, Sato T, Trimmer JS, Spiller BW, Clapham DE, Krulwich TA, Kawagishi I, Ito M (2007) The voltage gated $\mathrm{Na}^{+}$channel NaVBP colocalizes with methyl-accepting chemotaxis protein at cell poles of alkaliphilic Bacillus pseudofirmus OF4. Microbiology 153:4027-4038

Fujinami S, Terahara N, Krulwich TA, Ito M (2009) Motility and chemotaxis in alkaliphilic Bacillus species. Future Microbiol 4:1137-1149

Garnova ES, Zhilina TN, Tourova TP, Lysenko AM (2003) Anoxynatronum sibiricum gen.nov., sp.nov. alkaliphilic saccharolytic anaerobe from cellulolytic community of Nizhnee Beloe (Transbaikal region) Extremophiles 7:213-220

Gerasimenko LM, Dubinin AV, Mityushina LL, Zavarzin GA (1999) A microscopic green alga from soda lakes. Microbiology (Moscow, English translation) 68:696-700

Ghai R, Pašić L, Fernández AB, Martin-Cuadrado A, Mizuno CM, McMahon KD, Papke RT, Stepanauskas R, Rodriguez-Brito B, Rohwer F, Sánchez-Porro C, Ventosa A, Rodríguez-Valera (2011) New abundant microbial groups in aquatic hypersaline environments. Sci Rep 1:135

Ghosh W, Dam B (2009) Biochemistry and molecular biology of lithotrophic sulfur oxidation by taxonomically and ecologically diverse bacteria and archaea. FEMS Microbiol Rev 33:999-1043

Giri BJ, Bano N, Hollibaugh JT (2004) Distribution of RuBisCO genotypes along a redox gradient in Mono Lake, California. Appl Environ Microbiol 70:3443-3448

Gorlenko VM (2007) Anoxygenic phototrophic bacteria from soda lakes. Transactions of the Winogradsky Institute of Microbiology, vol XIV. Nauka, Moscow, pp 159-183

Gorlenko VM, Bryantseva IA, Panteleeva EE, Tourova TP, Kolganova TV, Makhneva ZK, Moskalenko AA (2004) Ectothiorhodosinus mongolicus gen. nov., sp. nov., a new purple bacterium from a soda lake in Mongolia. Microbiology (Moscow, English translation) 73:66-73

Gorlenko VM, Bryantseva IA, Rabold S, Tourova TP, Rubtsova D, Smirnova E, Thiel V, Imhoff JF (2009) Ectothiorhodospira variabilis sp. nov., an alkaliphilic and halophilic purple sulfur bacterium from soda lakes. Int J Syst Evol Microbiol 69: $558-564$ 
Grammann K, Volke A, Kunte HJ (2002) New type of osmoregulated solute transporter identified in halophilic members of the Bacteria domain: tRAP transporter TeaABC mediates uptake of ectoine and hydroxyectoine in Halomonas elongata DSM $2581^{\mathrm{T}}$. J Bacteriol 184:3078-3085

Grant WD, Sorokin DY (2011) Distribution and diversity of soda lake alkaliphiles. In: Horikoshi K, Antranikian G, Bull AT, Robb FT, Stetter KO (eds) Extremophiles handbook. Springer, New York, pp 27-54

Grant WD, Mwatha WE, Jones BE (1990) Alkaliphiles: ecology, diversity and applications. FEMS Microbiol Rev 75:255-270

Grant S, Grant WD, Jones BE, Kato C, Li L (1999) Novel archaeal phylotypes from an east African alkaline saltern. Extremophiles 3:139-145

Haines TH, Dencher NA (2002) Cardiolipin: a proton trap for oxidative phosphorylation. FEBS Lett 528:35-39

Hauss T, Dante S, Dencher NA, Haines TH (2002) Squalene is in the midplane of the lipid bilayer: implications for its function as a proton permeability barrier. Biochim Biophys Acta 1556: $149-154$

Hoeft SE, Switzer Blum J, Stolz JF, Tabita FR, Witte B, King GM, Santini JM, Oremland RS (2007) Alkalilimnicola ehrlichii sp. nov., a novel arsenite-oxidizing, haloalkaliphilic gammaproteobacterium capable of chemoautotrophic or heterotrophic growth with nitrate or oxygen as the electron acceptor. Int J Syst Evol Microbiol 57:504-512

Hoffmann T, von Blohn C, Stanek A, Moses S, Barzantny H, Bremer E (2012) Synthesis, release and recapture of compatible solute proline by osmotically stressed Bacillus subtilis cells. Appl Environ Microbiol 78:5753-5762

Hoover RB, Pikuta EV, Bej AK, Marsic D, Whitman WB, Tang J, Krader P (2003) Spirochaeta americana sp. nov., a new haloalkaliphilic, obligately anaerobic spirochaete isolated from soda Mono Lake in California. Int J Syst Evol Microbiol $53: 815-821$

Horikoshi K (2004) Alkaliphiles. Proc Jpn Acad B Phys Biol Sci $80: 166-178$

Horikoshi K (2006) Alkaliphiles: genetic properties and applications of enzymes. Springer, New York

Humayoun SB, Bano N, Hollibaugh JT (2003) Depth distribution of microbial diversity in Mono Lake, a meromictic soda lake in California. Appl Environ Microbiol 69:1030-1042

Hunte C, Screpanti E, Venturi M, Rimon A, Padan E, Michel H (2005) Structure of $\mathrm{Na}^{+} / \mathrm{H}^{+}$antiporter and insights into mechanism of action and regulation by $\mathrm{pH}$. Nature 435:1197-1202

Imhoff JF, Trueper HG (1981) Ectothiorhodospira abdelmalekii sp.nov., a new extremely halophilic and alkaliphilic phototrophic bacterium. Zentralbl Bakteriol Mikrobiol Hyg:1 Abt Orig C 2:228-234

Imhoff JF, Tindall BJ, Grant WD, Trüper HG (1981) Ectothiorhodospira vacuolata sp. nov., a new phototrophic bacterium from soda lakes. Arch Microbiol 130:238-242

Ito M, Guffanti AA, Zemsky J, Ivey DM, Krulwich TA (1997) Role of the nhaC-encoded $\mathrm{Na}^{+} / \mathrm{H}^{+}$antiporter of alkaliphilic Bacillus firmus OF4. J Bacteriol 179:3851-3857

Ito M, Xu H, Guffanti AA, Wei Y, Zvi L, Clapham DE, Krulwich TA (2004) The voltage-gated $\mathrm{Na}^{+}$channel NavBP has a role in motility, chemotaxis, and $\mathrm{pH}$ homeostasis of an alkaliphilic Bacillus. Proc Natl Acad Sci USA 101:10566-10571

Ito M, Terahara N, Fujinami S, Krulwich TA (2005) Properties of motility in Bacillus subtilis powered by the $\mathrm{H}^{+}$-coupled MotAB flagellar stator, $\mathrm{Na}^{+}$-coupled MotPS or hybrid stators MotAS or MotPB. J Mol Bio 352:396-408

Janssen AJ, Lens PN, Stams AJ, Plugge CM, Sorokin DY, Muyzer G, Buisman CJ (2009) Application of bacteria involved in the biological sulfur cycle for paper mill effluent purification. Sci Total Environ 407:1333-1343

Janto B, Ahmed A, Ito M, Liu J, Hicks DB, Pagni S, Fackelmayer OJ, Smith TA, Earl J, Elbourne LDH, Hassan K, Paulsen IT, Kolst $\varnothing$ AB, Tourasse NJ, Ehrlich GD, Boissy R, Ivey DM, Li G, Xue Y, Ma Y, Hu FZ, Krulwich TA (2011) Genome of alkaliphilic Bacillus pseudofirmus OF4 reveals adaptations that support the ability to grow in an external $\mathrm{pH}$ range from 7.5 to 11.4. Environ Microbiol 13:3289-3309

Joye SB, Connell TL, Miller LG, Oremland RS, Jellison RS (1999) Oxidation of ammonia and methane in an alkaline, saline lake. Limnol Oceanogr 44:178-188

Junier P, Molina V, Dorador C, Hadas O, Kim OS, Junier T, Witzel K-P, Imhoff JF (2010) Phylogenetic and functional marker genes to study ammonia-oxidizing microorganisms (AOM) in the environment. Appl Microbiol Biotechnol 85:425-440

Kaluzhnaya M, KhmeleninaV, Eshinimaev B, Suzina N, Nikitin D, Solonin A, Lin J-L, Mcdonald I, Murrell C, Trotsenko Y (2001) Taxonomic characterization of new alkaliphilic and alkalitolerant methanotrophs from soda lakes of the southeastern Transbaikal Region and description of Methylomicrobium buryatense sp.nov. Syst Appl Microbiol 24:166-176

Kalyuzhnaya MG, Khmelenina V, Eshinimaev B, Sorokin DYu, Fuse H, Lidstrom M, Trotsenko YA (2008) Reclassification and emended description of halo(alkali)philic and halo(alkali)tolerant methanotrophs of genera Methylomicrobium and Methylobacter. Int J Syst Evol Microbiol 58:591-596

Kevbrin VV, Lysenko AM, Zhilina TN (1997) Physiology of the alkaliphilic methanogen Z-7936, a new strain of Methanosalsus zhilinaeae isolated from Lake Magadi. Microbiologia 66: 315-320

Kevbrin VV, Zhilina TN, Rainey FA, Zavarzin GA (1998) Tindallia magadiigen. nov., sp. nov.: an alkaliphilic anaerobic ammonifier from soda lake deposits. Curr Microbiol 37:94-100

Kitada M, Hashimoto M, Kudo T, Horikoshi K (1994) Properties if two different $\mathrm{Na}^{+} / \mathrm{H}^{+}$antiport systems in alkaliphilic Bacillus sp. strain C-125. J Bacteriol 176:6464-6469

Kompantseva EI, Komova AV, Rusanov II, Pimenov NV, Sorokin DY (2009) Primary production of organic matter and phototrophic communities in the soda lakes of the Kulunda steppe (Altai, Russia). Microbiology 78:643-649

Kompantseva EI, Komova AV, Sorokin DY (2010) Communities of anoxygenic phototrophic bacteria in the saline soda lakes of the Kulunda Steppe (Altai Krai). Microbiology (Moscow, English translation) 79:89-95

Kompantseva EI, Komova AV, Novikov AA, Kostrikina NA (2012) Rhodovulum tesquicola sp. nov., a haloalkaliphilic purple nonsulfur bacterium from brackish steppe soda lakes. Int J Syst Evol Microbiol 62:2962-2966

Könneke M, Bernhard AE, de la Torre JR, Walker CB, Waterbury JB, Stahl DB (2005) Isolation of an ammonium-oxidizing marine archaeon. Nature 473:543-546

Kovaleva OL, Tourova TP, Muyzer G, Kolganova TV, Sorokin DY (2011) Diversity of RuBisCO and ATP citrate lyase genes in soda lake sediments. FEMS Microbiol Ecol 75:37-47

Krienitz L, Bock C, Kotut K, Luo W (2012) Picocystis salinarum (Chlorophyta) in saline lakes and hot springs of East Africa. Phycologia 51:22-32

Krienitz L, Dadheech PK, Kotut K (2013) Mass developments of the cyanobacteria Anabaenopsis and Cyanospira (Nostocales) in the soda lakes of Kenya: ecological and systematic implications. Hydrobiologia 703:79-93

Kulp TR, Hoeft SE, Miller LG, Saltikov C, Murphy JN, Han S, Lanoil B, Oremland RS (2006) Dissimilatory arsenate and sulfate reduction in sediments of two hypersaline, arsenic-rich soda 
lakes: mono and Searles Lakes, California. Appl Environ Microbiol 72:6514-6526

Kulp TR, Han S, Saltikov CW, Lanoil BD, Zargar K, Oremland RS (2007) Effects of imposed salinity gradients on dissimilatory arsenate reduction, sulfate reduction, and other microbial processes in sediments from two California soda lakes. Appl Environ Microbiol 73:5130-5137

Lanzen A, Simachew A, Gessesse A, Chmolowska D, Jonassen I, Øvreås L (2013) Surprising prokaryotic and eukaryotic diversity, community structure and biogeography of Ethiopian soda lakes. PLoS ONE 8:e72577

Levy-Sakin M, Berger O, Feibish N, Sharon N, Schnaider L, Shmul G, Amir Y, Buzhansky L, Gazit E (2014) The influence of chemical chaperones on enzymatic activity under thermal and chemical stresses: common features and variation among diverse chemical families. PLoSOne 9:e88541

Lin J, Radajewski S, Eshinimaev BT, Trotsenko YA, McDonald IR, Murrell JC (2004) Molecular diversity of methanotrophs in transbaikal soda lake sediments and identification of potentially active populations by stable isotope probing. Environ Microbiol 6:1049-1060

Ma Y, Zhang W, Xue Y, Zhou P, Ventosa A, Grant WD (2004) Bacterial diversity of the inner Mongolian Baer soda lake as revealed by $16 \mathrm{~S}$ rRNA gene sequence analyses. Extremophiles 8:45-51

Mathrani JM, Boone DR, Mah RA, Fox GE, Lau PP (1988) Methanohalophilus zhilinae sp. nov., an alkaliphilic, halophilic, methylotrophic methanogen. Int J Syst Bacteriol 38:139-142

McDonald IR, Bodrossy L, Chen Y, Murrell JC (2008) Molecular ecology techniques for the study of aerobic methanotrophs. Appl Environ Microbiol 75:1305-1315

Melack JM (1981) Photosynthetic activity of phytoplankton in tropical African soda lakes. Hydrobiologia 81:71-85

Mesbah NM, Wiegel $\mathrm{J}$ (2011) The $\mathrm{Na}^{+}$-translocating $\mathrm{F}_{1} \mathrm{~F}_{\mathrm{O}^{-}}$-ATPase from the halophilic, alkalithermophile Natranaerobius thermophilus. Biochim Biophys Acta 1807:1133-1142

Mesbah NM, Wiegel J (2012) Life under multiple extreme conditions: diversity and physiology of the halophilic alkalithermophiles. Appl Environ Microbiol 78:4074-4082

Mesbah NM, Abou-El-Ela SH, Wiegel J (2007) Novel and unexpected prokaryotic diversity in water and sediments of the alkaline, hypersaline lakes of the Wadi an Natrun, Egypt. Microbial Ecol 54:598-616

Mesbah NM, Cook GM, Wiegel J (2009) The halophilic alkalithermophile Natranaerobius thermophilus adapts to multiple environmental extremes using a large repertoire of $\mathrm{Na}^{+}\left(\mathrm{K}^{+}\right) / \mathrm{H}^{+}$ antiporters. Mol Microbiol 74:270-281

Mikhodyuk OS, Gerasimenko LM, Akimov VN, Ivanovsky RN, Zavarzin GA (2008) Ecophysiology and polymorphism of the unicellular extremely natronophilic cyanobacteriumEuhalothece sp. Z-M001 from lake Magadii. Microbiology 64:805-813

Milford AD, Achenbach LA, Jung DO, Madigan MT (2000) Rhodobaca bogoriensis gen. nov. and sp. nov., an alkaliphilic purple nonsulfur bacterium from African Rift Valley soda lakes. Arch Microbiol 174:18-27

Muyzer G, Sorokin DY, Mavromatis K, Lapidus A, Clum A, Ivanova N, Pati A, d'Haeseleer P, Woyke T, Kyrpides NC (2011) Complete genome sequence of Thioalkalivibrio sulfidophilus HL-EbGr7. Stand Genomic Sci 4:23-35

Muyzer G, Sorokin DY, Mavromatis K, Lapidus A, Klum A, Ivanova N, Pati A, d'Haeseleer P, Woyke T, Kyrpides NC (2012) Complete genome sequence of Thioalkalivibrio sp. K90mix. Standards Genomic Sci 5:341-355

Namsaraev BB, Zhilina TN, Kulyrova AV, Gorlenko VM (1999) Bacterial methanogenesis in soda lakes of the southeastern Transbaikal region. Microbiology (Moscow) 68:586-591
Nolla-Ardèvol V, Strous M, Sorokin DY, Merkel AY, Tegetmeyer HE (2012) Activity and diversity of haloalkaliphilic methanogens in Central Asian soda lakes. J Biotechnol 161:167-173

Ochsenreiter T, Pfeifer F, Schleper C (2002) Diversity of archaea in hypersaline environments characterized by molecular-phylogenetic and cultivation studies. Extremophiles 6:267-274

Oremland RS (1990) Nitrogen fixation dynamics of two diazotrophic communities in Mono Lake, California. Appl Environ Microbiol 56:614-622

Oremland RS, Boone DR (1994) Methanolobus taylorii sp. nov., a new methylotrophic, estuarine methanogen. Int J Syst Bacteriol 94:573-575

Oremland RS, Miller LG (1993) Biogeochemistry of natural gases in three alkaline, permanently stratified (meromictic) lakes. In: Howell DG (ed) The future of energy gases, USGS Professional paper 1570, Washington DC, pp 453-470

Oren A (1994) The ecology of the extremely halophilic archaea. FEMS Microbiol Rev 13:415-439

Oren A (1999) Bioenergetic aspects of halophilism. Microbiol Mol Biol Rev 63:334-348

Oren A (2011) Thermodynamic limits to microbial life at high salt concentrations. Environ Microbiol 13:1908-1923

Oren A (2013) Life at high salt concentrations, intracellular $\mathrm{KCl}$ concentrations and acidic proteomes. Front Microbiol 4:315

Padan E, Bibi E, Ito M, Krulwich TA (2005) Alkaline $\mathrm{pH}$ homeostasis in bacteria: new insights. Biochim Biophys Acta 1717:67-88

Pagaling E, Wang H, Venables M, Wallace A, Grant WD, Cowan DA, Jones BE, Ma Y, Ventosa A, Heaphy S (2009) Microbial biogeography of six salt lakes in inner Mongolia, China, and a salt lake in Argentina. Appl Environ Microbiol 75:5750-5760

Pikuta EV, Zhilina TN, Zavarzin GA, Kostrikina NA, Osipov GA, Rainey FA (1998) Desulfonatronum lacustre gen. nov., sp. nov.: a new alkaliphilic sulfate-reducing bacterium utilizing ethanol. Microbiology (Moscow, English translation) 67:105-113

Pikuta EV, Hoover RB, Bej AK, Marsic D, Whitman WB, Cleland D, Krader P (2003a) Desulfonatronum thiodismutans sp. nov., a novel alkaliphilic, sulfate-reducing bacterium capable of lithoautotrophic growth. Int J Syst Evol Microbiol 53:1327-1332

Pikuta EV, Hoover RB, Bej AK, Marsic D, Detkova EN, Whitman WB, Krader P (2003b) Tindallia californiensis sp. nov., a new anaerobic, haloalkaliphilic, spore-forming acetogen isolated from Mono lake in California. Extremophiles 7:327-334

Pinner E, Kotler Y, Padan E, Schuldiner S (1993) Physiological role of $\mathrm{NhaB}$, a specific $\mathrm{Na}^{+} / \mathrm{H}^{+}$antiporter in Escherichia coli. J Biol Chem 25:1729-1734

Poser A, Vogt C, Knoeller K, Finster K, Sorokin DY, Lohmayer R, Planer-Friedrich B, Richnow H-H (2013) Disproportionation of elemental sulfur by haloalkaliphilic bacteria from soda lakes. Extremophiles 17:1003-1012

Rees HC, Grant WD, Jones BE, Heaphy S (2004) Diversity of Kenyan soda lake alkaliphiles assessed by molecular methods. Extremophiles 8:63-71

Rodriguez-Valera F, Ventosa A, Juez G, Imhoff JF (1985) Variation of environmental features and microbial populations with salt concentrations in a multi-pond saltern. Microb Ecol 11:107-115

Roesler CS, Culbertson CW, Etheride SM, Goericke R, Kiene RP, Miller LM, Oremland RS (2002) Distribution, production, andecophysiology of Picocystis strain ML in Mono Lake, California. Limnol Oceanogr 47:440-452

Rössler M, Müller V (2001) Osmoadaptation in bacteria and archaea: common principles and differences. Environ Microbiol 3:743-745

Roychoudhury A, Bieker A, Haeussinger D, Oesterhelt F (2013) Membrane protein stability depends on the concentration of compatible solutes-a single molecule force spectroscopic study. Biol Chem 394:1465-1474 
Scholten J, Joye S, Hollibaugh J, Murrell J (2005) Molecular analysis of the sulfate reducing and archaeal community in a meromictic soda lake (Mono Lake, California) by targeting 16S rRNA, $m c r A$, apsA, and $d s r A B$ genes. Microb Ecol 50:29-39

Shapovalova AA, Hizhniak TV, Tourova TP, Muyzer G, Sorokin DY (2009) Halomonas chromatireducens sp. nov., a novel haloalkaliphile from soda soil capable of aerobic chromate reduction. Microbiology (Moscow) 78:117-127

Slonczewski JL, Fujisawa M, Dopson M, Krulwich TA (2009) Cytoplasmic $\mathrm{pH}$ measurement and homeostasis in bacteria and archaea. Adv Microb Physiol 55:1-80

Sorokin DY (1998) Occurrence of nitrification in extremely alkaline natural habitats. Microbiology 67:404-408

Sorokin DY, Kuenen JG (2005) Alkaliphilic chemolithotrophs from sodas lakes. FEMS Microbiol Ecol 52:287-295

Sorokin DY, Muyzer G (2010) Desulfurispira natronophila gen. nov. sp. nov.: an obligately anaerobic dissimilatory sulfur-reducing bacterium from soda lakes. Extremophiles 14:349-355

Sorokin DY, Muyzer G, Brinkhoff T, Kuenen JG, Jetten MSM (1998) Isolation and characterization of a novel facultatively alkaliphilic Nitrobacter species, N. alkalicus sp. nov. Arch Microbiol 170:345-352

Sorokin DY, Jones BE, Kuenen JG (2000) A novel methane-oxidizing bacterium from highly alkaline environment. Extremophiles $4: 145-155$

Sorokin DY, Lysenko AM, Mityushina LL, Tourova TP, Jones BE, Rainey FA, Robertson LA, Kuenen JG (2001a) Thioalkalimicrobium aerophilum gen. nov., sp. nov. and Thioalkalimicrobium sibiricum. sp. nov., and Thioalkalivibrio versutus gen. nov., sp. nov., Thioalkalivibrio nitratis sp. nov. and Thioalkalivibrio denitrificans sp. nov., novel obligately alkaliphilic and obligately chemolithoautotrophic sulfur-oxidizing bacteria from soda lakes. Int J Syst Evolution Microbiol 51:565-580

Sorokin DY, Kuenen JG, Jetten M (2001b) Denitrification at extremely alkaline conditions in obligately autotrophic alkaliphilic sulfur-oxidizing bacterium Thioalkalivibrio denitrificans. Arch Microbiol 175:94-101

Sorokin DY, Tourova TP, Lysenko AM, Kuenen JG (2001c) Microbial thiocyanate utilization under highly alkaline conditions. Appl Environ Microbiol 67:528-538

Sorokin DY, Gorlenko, VM, Tourova, TP, Kolganova TV, Tsapin AI, Nealson KH, Kuenen JG (2002a) Thioalkalimicrobium cyclum sp. nov. and Thioalkalivibrio jannaschii sp. nov., new species of alkaliphilic, obligately chemolithoautotrophic sulfur-oxidizing bacteria from a hypersaline alkaline Mono Lake (California). Int J Syst Evolut Microbiol 52:913-920

Sorokin DY, Tourova TP, Lysenko AM, Mityushina LL, Kuenen JG (2002b) Thioalkalivibrio thiocyanooxidans sp. nov. and Thioalkalivibrio paradoxus sp. nov., novel alkaliphilic, obligately autotrophic, sulfur-oxidizing bacteria from the soda lakes able to grow with thiocyanate. Int J Syst Evolut Microbiol 52:657-664

Sorokin DY, Tourova TP, Kolganova TV, Sjollema KA, Kuenen JG (2002c) Thioalkalispira microaerophila gen. nov., sp. nov., a novel lithoautotrophic, sulfur-oxidizing bacterium from a soda lake. Int J Syst Evol Micorbiol 52:2175-2182

Sorokin DY, Antipov AN, Kuenen JG (2003) Complete denitrification in a coculture of haloalkaliphilic sulfur-oxidizing bacteria from a soda lake. Arch Microbiol 180:127-133

Sorokin DY, Gorlenko VM, Namsaraev BB, Namsaraev ZB, Lysenko AM, Eshinimaev BT, Khmelenina VN, Trotsenko YA (2004a) Prokaryotic communities of the north-eastern Mongolian soda lakes. Hydrobiologia 522:235-248

Sorokin DY, Tourova TP, Antipov AN, Muyzer G, Kuenen JG (2004b) Anaerobic growth of the haloalkaliphilic denitrifying sulphur-oxidising bacterium Thialkalivibrio thiocyanodenitrificans sp. nov.with thiocyanate. Microbiology 150:2435-2442
Sorokin DY, Zhilina TN, Spiridonova EM, Tourova TP, Lysenko AM (2006) Increased metabolic versatility of haloalkaliphilic bacteria belonging to the Alkalispirillum-Alkalilimnicola group from soda lakes. Extremophiles 10:213-220

Sorokin DY, Foti M, Pinkart HC, Muyzer G (2007a) Sulfur-oxidizing bacteria in Soap Lake(Washington, USA), a meromictic, haloalkaline lake with an unprecedented high sulfidecontent. Appl Environ Microbiol 73:451-455

Sorokin DY, Foti M, Tindall BJ, Muyzer G (2007b) Desulfurispirillum alkaliphilum gen. nov. sp. nov., a novel obligately anaerobic sulfur- and dissimilatory nitrate-reducing bacterium from a full-scale sulfide-removing bioreactor. Extremophiles 11:363-370

Sorokin DY, Tourova TP, Henstra AM, Stams AJM, Galinski EA, Muyzer G (2008a) Sulfidogenesis at extremely haloalkaline conditions by Desulfonatronospira thiodismutans gen. nov., sp. nov., and Desulfonatronospira delicata sp. nov. - a novel lineage of Deltaproteobacteria from hypersaline soda lakes. Microbiology $154: 1444-1453$

Sorokin DY, Tourova TP, Mussmann M, Muyzer G (2008b) Dethiobacter alkaliphilus gen. nov. sp. nov., and Desulfurivibrio alkaliphilus gen. nov. sp. nov. - two novel representatives of reductive sulfur cycle from soda lakes. Extremophiles 12:431-439

Sorokin ID, Kravchenko IK, Doroshenko EV, Boulygina ES, Zadorina EV, Tourova TP, Sorokin DY (2008c) Haloalkaliphilic diazotrophs in soda solonchak soils. FEMS Microbiol Ecol 65:425-433

Sorokin ID, Kravchenko IK, Tourova TP, Kolganova TV, Boulygina ES, Sorokin DY (2008d) Bacillus alkalidiazotrophicus sp. nov., a diazotrophic, low salt-tolerant alkaliphile from Mongolian soda soil. Int J Syst Evol Microbiol 58:2459-2464

Sorokin ID, Kravchenko IK, Tourova TP, Boulygina ES, Sorokin DY (2008e) Natronobacillus azotifigens gen. nov. sp. nov., anaerobic diazotrophic haloalkaliphile from soda-rich habitats. Extremophiles 12:819-827

Sorokin DY, van den Bosch PLF, Janssen AJH, Muyzer G (2008f) Microbiological analysis of the population of extremely haloalkaliphilic sulfur-oxidizing bacteria dominating in lab-scale sulfideremoving bioreactors. Appl Microbiol Biotechnol 80:965-975

Sorokin DY, van Pelt S, Tourova TP, Evtushenko LI (2009) Nitriliruptor alkaliphilus gen. nov., sp. nov. a deep lineage haloalkaliphilic actinobacterium from soda lakes capable of growth on aliphatic nitriles and proposal of Nitriliruptoraceae fam. nov. and Nitriliruptorales ord. nov. Int J Syst Evol Microbiol 59:248-253

Sorokin DY, Rusanov II, Pimenov NV, Tourova TP, Abbas B, Muyzer G (2010a) Sulfidogenesis under extremely haloalkaline conditions in soda lakes of Kulunda steppe (Altai, Russia). FEMS Microbiol Ecol 73:278-290

Sorokin DY, Detkova EN, Muyzer G (2010b) Propionate and butyrate dependent bacterial sulfate reduction at extremely haloalkaline conditions and description of Desulfobotulus alkaliphilus sp. nov. Extremophiles 14:71-77

Sorokin DY, Panteleeva AN, Tourova TP, Kaparullina EN, Muyzer G (2011a) Natronoflexus pectinivorans gen. nov., sp. nov., an obligately anaerobic and alkaliphilic fermentative member of Bacteroidetes from soda lakes. Extremophiles 15:691-696

Sorokin DY, Kuenen JG, Muyzer G (2011b) The microbial sulfur cycle in soda lakes. Front Microbial Physiol 2:44

Sorokin DY, Tourova TP, Detkova EN, Kolganova TV, Galinski EA, Muyzer G (2011c) Culturable diversity of lithotrophic haloalkaliphilic sulfate-reducing bacteria in soda lakes and the description of Desulfonatronum thioautotrophicum sp. nov., Desulfonatronum thiosulfatophilum sp. nov., Desulfonatronovibrio thiodismutans sp. nov., and Desulfonatronovibrio magnus sp. nov. Extremophiles 15:391-401 
Sorokin DY, Detkova EN, Muyzer G (2011d) Sulfur-dependent respiration at extremely haloalkaline conditions in soda lake "acetogens" and the description of Natroniella sulfidigena sp. nov. FEMS Microbiol Lett 319:88-95

Sorokin DY, Tourova TP, Mordanov AV, Ravin NV (2012a) Microbial chitin utilization at extremely haloalkaline conditions. Extremophiles 16:883-894

Sorokin DY, Tourova TP, Panteleeva AN, Kaparullina EN, Muyzer G (2012b) Anaerobic utilization of pectinous substrates at extremely haloalkaline conditions by Natranaerovirga pectinivora gen. nov., sp. nov., and Natranaerovirga hydrolytica sp. nov., isolated from hypersaline soda lakes. Extremophiles 16:307-315

Sorokin DY, Panteleeva AN, Tourova TP, Muyzer G (2012c) Haloalkaliphilic heterotrophic sulfate-reducing bacteria from soda lakes and description of Desulfonatronobacter acidivorans gen. nov., sp. nov., and Desulfobulbus alkaliphilus sp. nov. Int J Syst Evol Microbiol 62:2107-2113

Sorokin DY, Tourova TP, Sukhacheva MV, Muyzer G (2012d) Desulfuribacillus alkaliarsenatis gen. nov. sp. nov., a deeplineage, obligately anaerobic, dissimilatory sulfur and arsenatereducing, haloalkaliphilic representative of the order Bacillales from soda lakes. Extremophiles 16:597-605

Sorokin DY, Tourova TP, Muyzer G (2013a) Isolation and characterization of two novel alkalitolerant sulfidogens from a Thiopaq bioreactor, Desulfonatronum alkalitolerans sp. nov., and Sulfurospirillum alkalitolerans sp. nov. Extremophiles 17:535-543

Sorokin DY, Banciu H, Robertson LA, Kuenen JG, Muyzer G (2013b) Halophilic and haloalkaliphilic sulfur-oxidizing bacteria from hypersaline habitats and soda lakes. In: Rosenberg E, DeLong EF, Lory S, Stackebrandt E, Thompson F (eds) The Prokaryotes-Prokaryotic Physiology and Biochemistry, 4th edn. Springer, Berlin, pp 530-551

Sorokin DY, Gumerov VM, Rakitin AL, Beletsky AV, Damsté JS, Mardanov AV, Ravin NV (2014a) Genome analysis of Chitinivibrio alkaliphilus gen. nov., sp. nov., a novel extremely haloalkaliphilic anaerobic chitinolytic bacterium from the candidate phylum TG3. Environ Microbiol 16:1549-1565

Sorokin DY, Abbas B, Tourova TP, Bumazhkin BK, Kolganova TV, Muyzer G (2014b) Sulfate-dependent acetate oxidation at extremely natron-alkaline conditions by syntrophic associations from hypersaline soda lakes. Microbiology 160:723-732

Talon R, Coquelle N, Madern D, Girard E (2014) An experimental point of view on hydration/solvation in halophilic proteins. Front Microbiol 5:66

Tenchov B, Vescio EM, Sprott GD, Zeidel ML, Mathai JC (2006) Salt tolerance of archaeal extremely halophilic lipid membranes. J Biol Chem 281:10016-10023

Terahara N, Sano M, Ito M (2012) A Bacillus flagellar motor that can use both $\mathrm{Na}^{+}$and $\mathrm{K}^{+}$as a coupling ion is converted by a single mutation to use only $\mathrm{Na}^{+}$. PLoS ONE 7(9):e46248

Tindall BJ (1988) Prokaryotic life in the alkaline, saline, athalassic environment. Halophilic bacteria 1:31-67

Tourova TP, Spiridonova EM, Berg IA, Slobodova NV, Boulygina ES, Sorokin DY (2007) Phylogeny and evolution of the family Ectothiorhodospiraceae based on comparison of $16 \mathrm{~S}$ rRNA, cbbL and nifH genes. Int J System Evol Microbiol 57:2387-2398

Tourova TP, Slobodova NV, Bumazhkin BK, Kolganova TV, Muyzer G, Sorokin DY (2013) Analysis of community composition of sulfur-oxidizing bacteria in hypersaline and soda lakes using soxB as a functional molecular marker. FEMS Microbiol Ecol 84:280-289

Trotsenko YA, Khmelenina VN (2002) Biology of extremophilic and extremotolerant methanotrophs. Arch Microbiol 177:123-131

van de Vossenberg JLCM, Driessen AJM, Grant WD, Konings WN (1999) Lipid membranes from halophilic and alkali-halophilic
Archaea have a low $\mathrm{H}^{+}$and $\mathrm{Na}^{+}$permeability at high salt concentration. Extremophiles 3:253-257

van den Bosch PL, van Beusekom OC, Buisman CJ, Janssen AJ (2007) Sulfide oxidation at halo-alkaline conditions in a fedbatch bioreactor. Biotech Bioeng 97:1053-1063

van Pelt S, Quignard S, Kubáč D, Sorokin DY, van Rantwijk F, Sheldon RA (2008) Nitrile hydratase CLEAs: the immobilization and stabilization of an industrially important enzyme from an alkaliphilic bacterium. Green Chem 10:395-400

VerBerkmoes NC, Denef VJ, Hettich RL, Banfield JF (2009) Systems biology: functional analysis of natural microbial consortia using community proteomics. Nature Rev Microbiol 7:196-205

Wagner M, Loy A, Klein M, Lee N, Ramsing NB, Stahl DA, Friedrich MW (2005) Functional marker genes for identification of sulfate-reducing prokaryotes. Meth Enzymol 397:469-489

Watson GM, Tabita FR (1997) Microbial ribulose 1, 5-bisphosphate carboxylase/oxygenase: a molecule for phylogenetic and enzymological investigation. FEMS Microbiol Lett 146:13-22

Wei Y, Guffanti AA, Ito M, Krulwich TA (2000) Bacillus subtilis Yqkl is a novel maic/ $\mathrm{Na}(+)$-lactate antiporter that enhances growth on malate at low protonmotive force. J Biol Chem 275:30287-30292

Zavarzin GA, Zhilina TN (2000) Anaerobic chemotrophic alkaliphiles. In: Seckbach J (ed) Journey to diverse microbial worlds. Kluwer Academic Publishers, Netherlands, pp 191-208

Zavarzin GA, Zhilina TN, Kevbrin VV (1999) The alkaliphilic microbial community and its functional diversity. Microbiology 68:503-521

Zavarzina DG, Kolganova TV, Boulygina ES, Kostrikina NA, Tourova TP, Zavarzin GA (2006) Geoalkalibacter ferrihydriticusgen. nov. sp. nov., the first alkaliphilic representative of the family Geobacteraceae isolated from a soda lake. Microbiology 75:673-682

Zavarzina DG, Tourova TP, Kolganova TV, Boulygina ES, Zhilina TN (2009) Description of Anaerobacillus alkalilacustre gen. nov., sp nov.-Strictly anaerobic diazotrophic bacillus isolated from soda lake and transfer of Bacillus arseniciselenatis, Bacillus macyae, and Bacillus alkalidiazotrophicus to Anaerobacillus as the new combinations A. arseniciselenatis comb. nov., A. macyae comb. nov., and A. alkalidiazotrophicus comb. nov. Microbiology (Moscow, English translation) 78:723-731

Zavrel M, Bross D, Funke M, Büchs J, Spiess AC (2009) High throughput screening for ionic liquids dissolving (lingo-)cellulose. Bioresour Technol 10:2580-2587

Zhang T, Datta S, Eichler J, Ivanova N, Axen SD, Kerfeld CA, Rubin E (2011) Identification of a haloalkaliphilic and thermostable cellulose with improved ionic liquid tolerance. Green Chem 13:2083-2090

Zhilina TN, Zavarzin GA, Detkova EN, Rainey FA (1995) Natroniella acetigena gen. nov. sp. nov., an extremely haloalkaliphilic, homoacetic bacterium: a new member of Haloanaerobiales. Curr Microbiol 32:320-326

Zhilina TN, Zavarzin GA, Rainey FA, Kevbrin VV, Kostrikana NA, Lysenko AM (1996) Spirochaeta alkalica sp. nov. and Spirochaeta africana sp. nov., alkaliphilic anaerobes from the continental soda lakes in Central Asia and East African Rift. Int J Syst Bact 46:305-312

Zhilina TN, Zavarzin GA, Rainey FA, Pikuta EN, Osipou GA, Kostrikina NA (1997) Desulfonatronovibrio hydrogenovorans gen. nov., sp. nov., an alkaliphilic, sulphate-reducing bacterium. Int J Syst Bacteriol 47:144-149

Zhilina TN, Detkova EN, Rainey FA, Osipov GA, Lysenko AM, Kostrikina NA, Zavarzin GA (1998) Natronoincola histidinovorans gen. nov., sp. nov., a new alkaliphilic acetogenic anaerobe. Curr Microbiol 37:177-185

Zhilina TN, Appel R, Probian C, Brossa EL, Harder J, Widdel F, Zavarzin GA (2004) Alkaliflexus imshenetskii gen. nov. sp. nov., 
a new alkaliphilic gliding carbohydrate-fermenting bacterium with propionate formation from a soda lake. Arch Microbiol 182:244-253

Zhilina TN, Kevbrin VV, Tourova TP, Lysenko AM, Kostrikina NA, Zavarzin GA (2005a) Clostridium alkalicellumsp. nov., an obligately alkaliphilic cellulolytic bacterium from a soda lake in the Baikal region. Microbiology 74:557-566

Zhilina TN, Zavarzina DG, Kolganova TV, Tourova TP, Zavarzin GA (2005b) Candidatus "Contubernalis alkalaceticum", an obligately syntrophic alkaliphilic bacterium capable of anaerobic acetate oxidation in a coculture with Desulfonatronum cooperativum. Microbiology 74:695-703
Zhilina TN, Zavarzina DG, Panteleeva AN, Osipov GA, Kostrikina NA, Tourova TP, Zavarzin GA (2012) Fuchsiella alkaliacetigenagen. nov., sp. nov., an alkaliphilic, lithoautotrophic homoacetogen from a soda lake. Int J Syst Evol Microbiol 62:1666-1673

Zhilina TN, Zavarzina DG, Kevbrin VV, Kolganova TV (2013) Methanocalculus natronophilus sp. nov., a new alkaliphilic hydogenotrophic methanogenic archaeon from soda lake and proposal of the new family Methanocalculaceae. Microbiology (Moscow, English translation) 82:698-706

Zhu S (2008) Use of ionic liquids for the efficient utilization of lignocellulosic materials. J Chem Tech Biotech 83:777-779 